
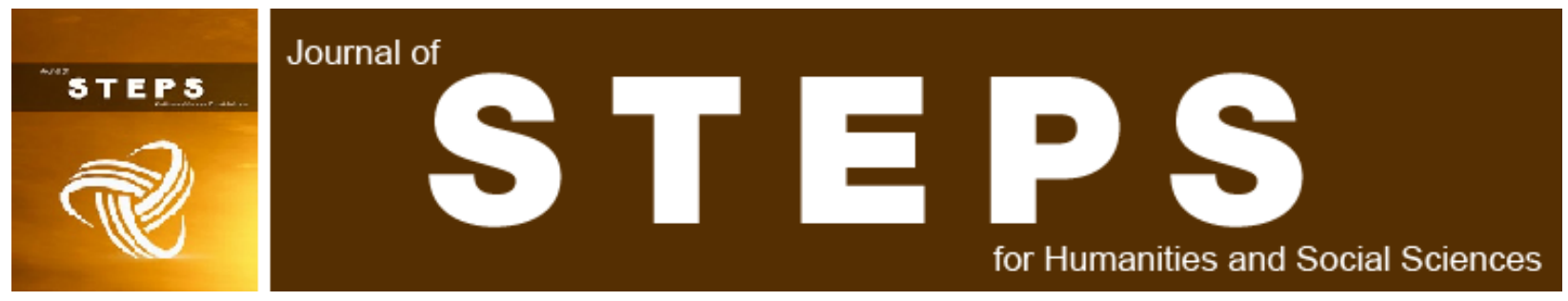

Volume 1 | Issue 1

Article 3

\title{
The status of Arab urban centers in the geographical heritage
}

Amenah Hasan Niyazi

Wasit University, Iraq, aniyazi@uowasit.edu.iq

Follow this and additional works at: https://www.steps-journal.com/jshss

Part of the Arts and Humanities Commons

\section{Recommended Citation}

Niyazi, Amenah Hasan (2022) "The status of Arab urban centers in the geographical heritage," Journal of STEPS for Humanities and Social Sciences: Vol. 1 : Iss. 1 , Article 3.

Available at: https://doi.org/10.55384/2790-4237.1006

This Original Study is brought to you for free and open access by Journal of STEPS for Humanities and Social Sciences (STEPS). It has been accepted for inclusion in Journal of STEPS for Humanities and Social Sciences by an authorized editor of Journal of STEPS for Humanities and Social Sciences (STEPS). 


\section{اوضاع مراكز العمران العربية في التراث الجغرافي}

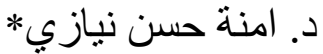

يعد ظهور الإسلام من أكثر الأحداث البشرية أهمية في حياة البشر. و أشعل ثورة عمر انية أصبحت مركز

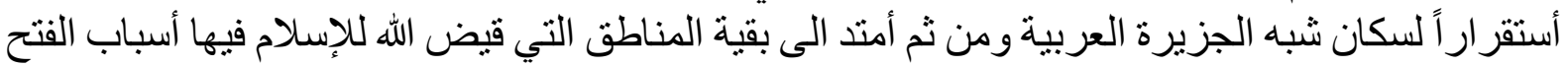

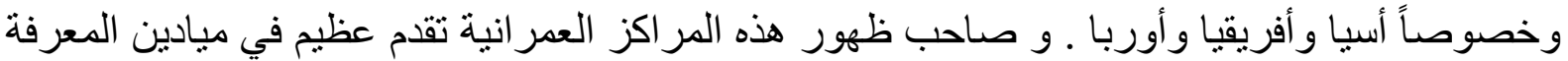

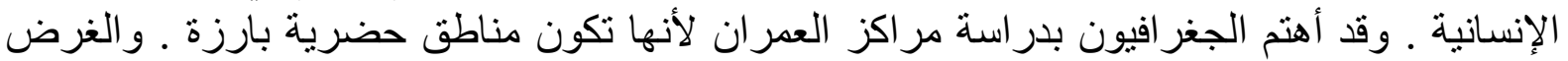

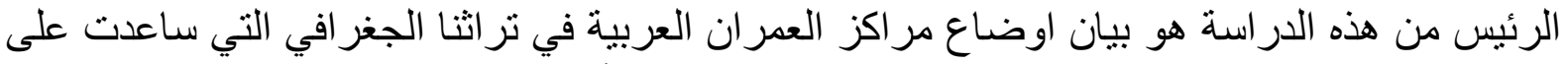

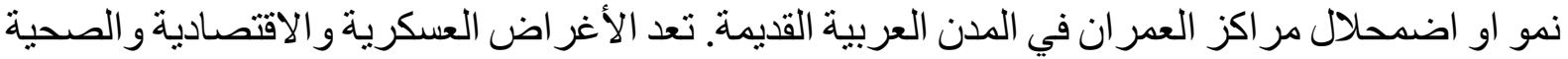

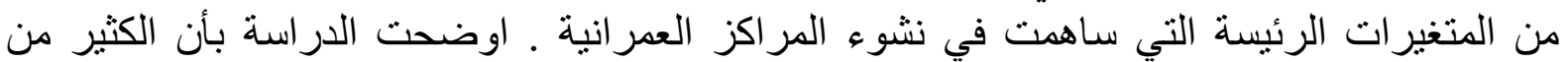
المتغير ات التي ساعدت على نشوء المر اكز العمر انية في المر احل الأولى قد فقدت وظيفتها واتهئ أنمحى كيانها

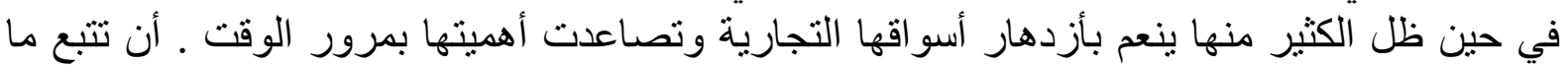

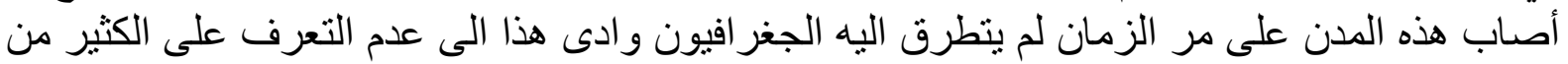
الحقائق التي ادت الى ضدن المدئ هرر ها أو أزدهار هان.

كلمات مفتاحية: مر اكز العمران، التراث الجغر افي، فكر جغر افي.

* دكتور اة، قسم الجغر افية، كلية التربية للعلوم الإنسانية، جامعة و اسط، العر اق. aniyazi@uowasit.edu.iq 


\title{
The status of Arab urban centers in the geographical heritage
}

Dr. Amenah Hasan Niyazi, Geography Department, College of Education for Human Sciences, Wasit University, Iraq.

\begin{abstract}
The emergence of Islam is one of the most important human events in human life. It results in an urban revolution that became a center of stability for the inhabitants of the Arabian Peninsula and then spread to the rest of the regions, especially Asia, Africa, and Europe. The emergence of these urban centers was accompanied by great progress in the fields of human knowledge. Geographers have been interested in studying urban centers because they are prominent urban areas. Thus, the main purpose of this study is the formation of basic concepts that help in knowing the growth or decline of urban centers in the ancient Arab cities. The main purpose of this study is to clarify the conditions of Arab urban centers in our geographical heritage that helped the growth or decline of urban centers in ancient Arab cities. Military, economic, and health purposes are among the main variables that contributed to the emergence of urban centers. The study clarified that many of the variables that helped in the emergence of urban centers in the early stages have lost their role and erased their entity, while many of them continued to enjoy the prosperity of their commercial markets and their importance increased over time. The tracking of what happened to these cities over time was not followed by geographers and this led to the failure to identify many of the facts that led to their decrease or prosperity.
\end{abstract}

Keywords: urban centers, geographical heritage, geographical thought. 
تزخر كتب التراث الجغر افي العربي بذكر الامكنة و البقاع في مختلف نو احي الارض وضتوستوسع معاجم اللغة

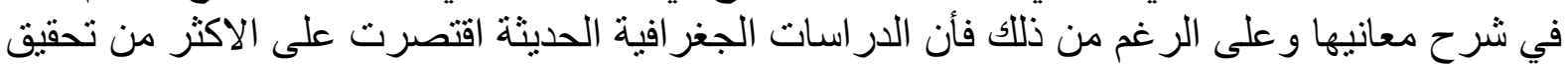

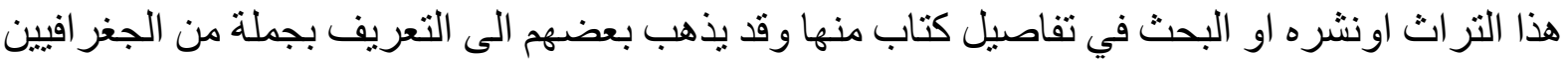

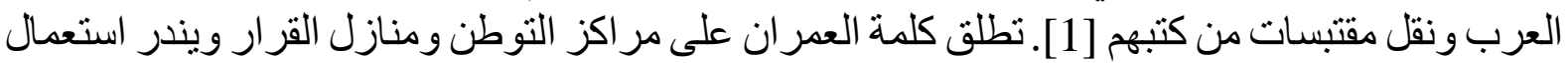

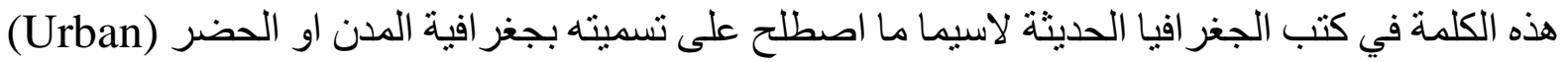

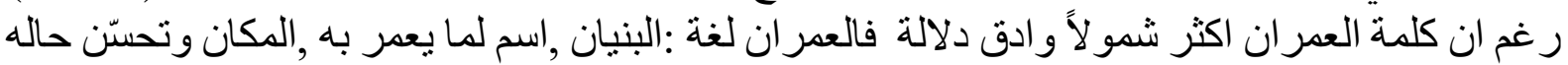

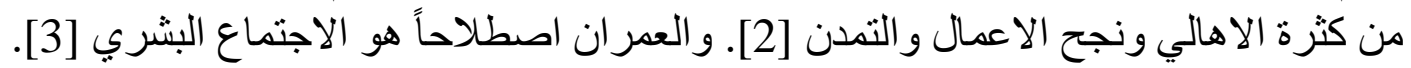

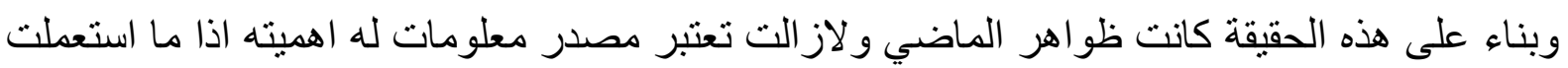

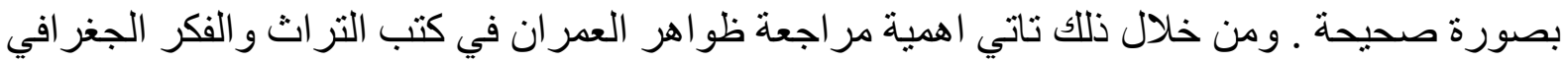

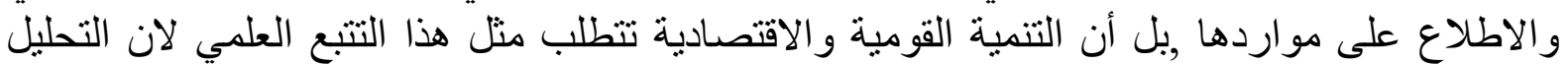

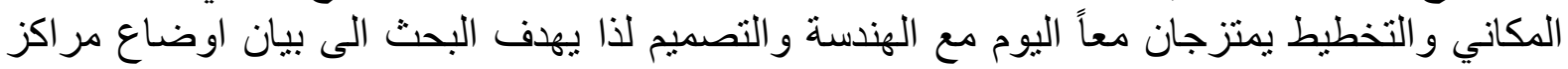

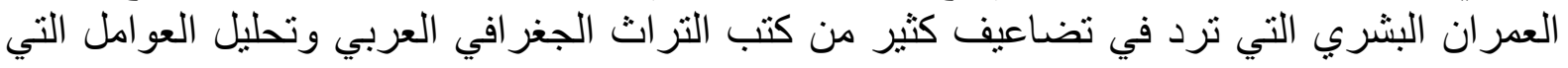

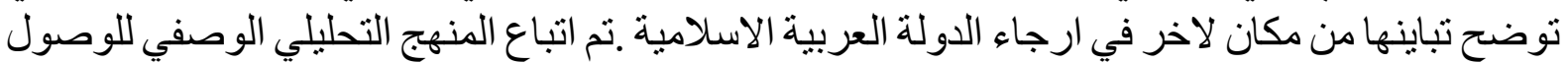

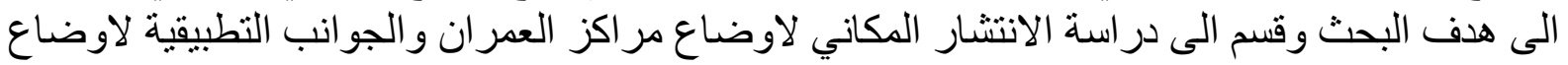

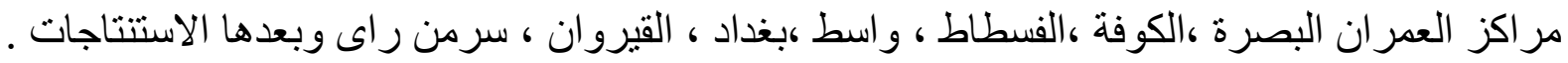

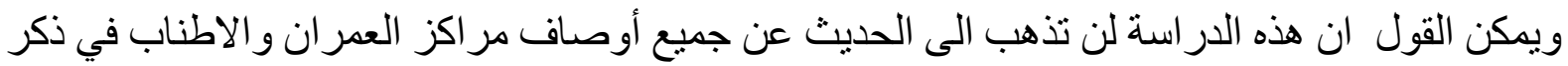

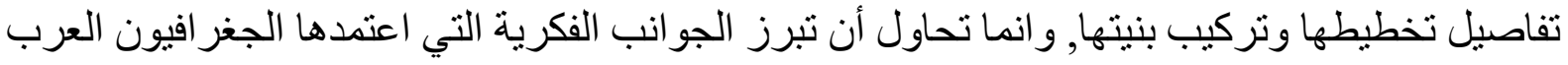

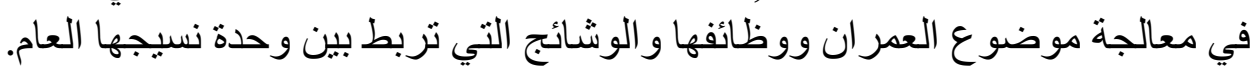

الانتثار المكاني لاوضاع مراكز العمران

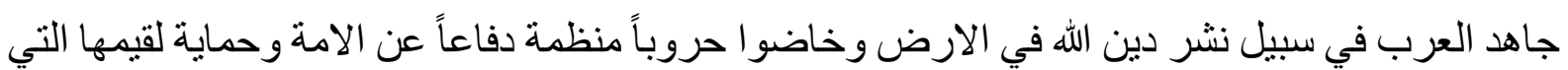

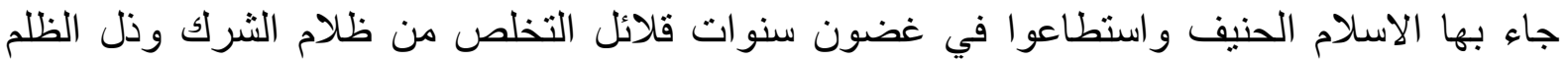

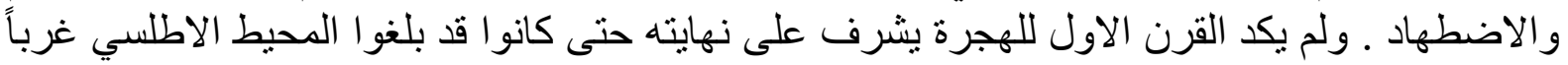

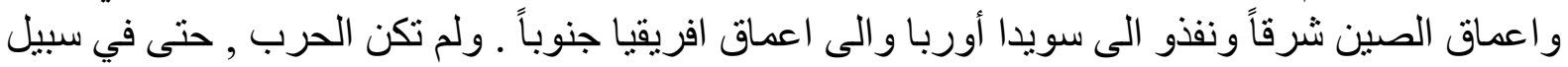

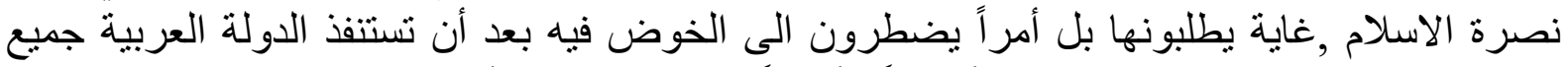

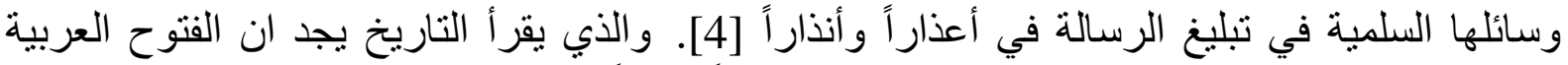

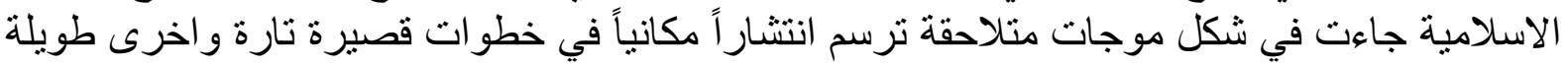

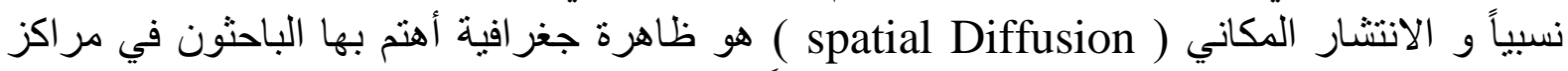

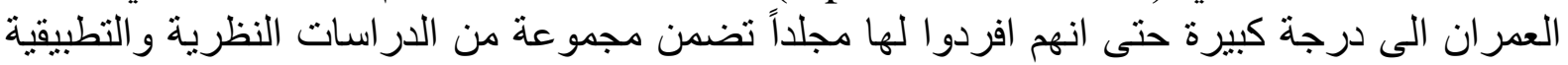

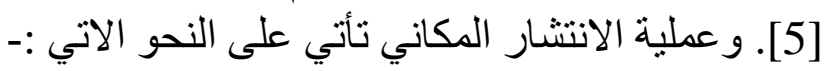

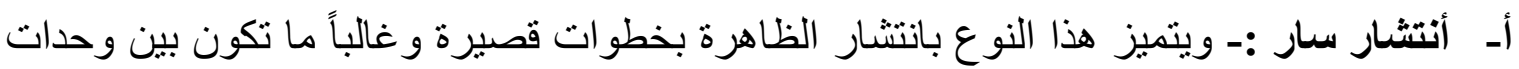
مساحية متجاورة او تللك التي تعادلها في الاهمية.

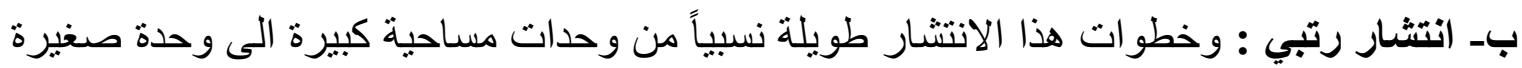

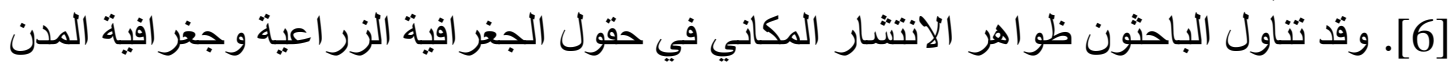

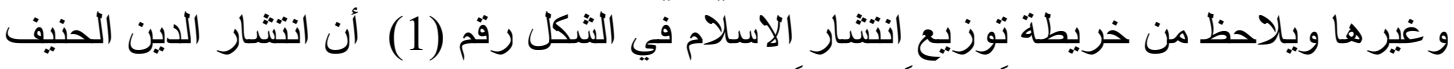

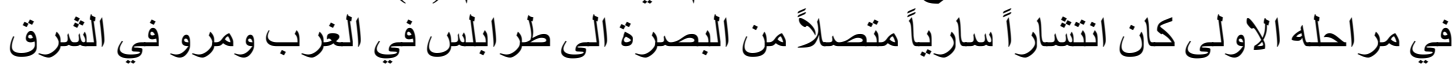

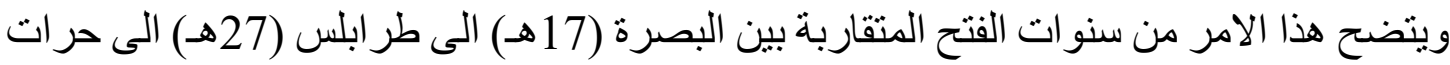

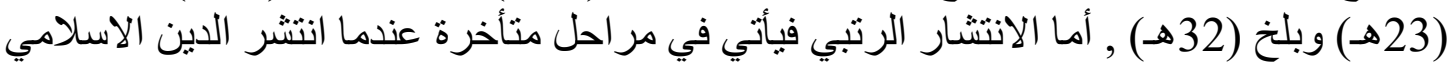


في رقعة واسعة من المعمورة وضرب بجر انه , عندما اتسعت رقعة الاسلام وبلغت الاندلس غرباً

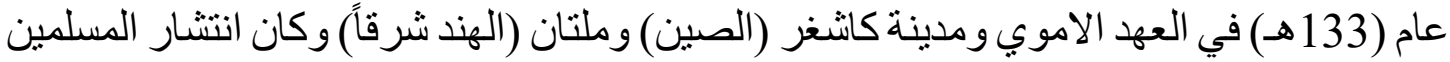
يمتد عام (288هـ) في العهد العباسي الى سواحل البحر المتوسط الثمالية وجزره ، مثل فئل صقلية

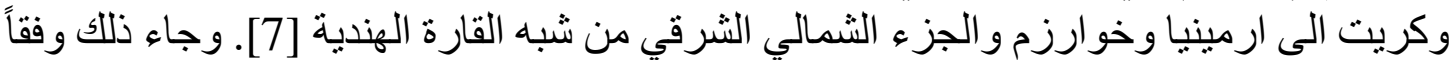

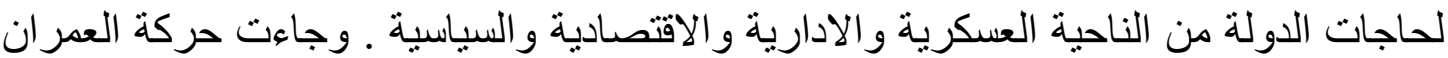

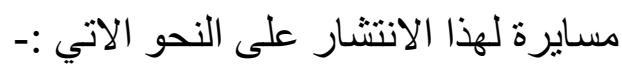
أــ بناء مر اكز عمر انية جديدة مثل البصرة و الكوفة و الفسطاط و القيروان و غير ها . بـ توسع مر اكز عمر انية قديمة و اطر اد نمو ها مثل دمثن وحماة وبعلبك وجدة وسلا (في المغرب على لئ الجهة المقابلة لمدينة الرباط الحديثة).

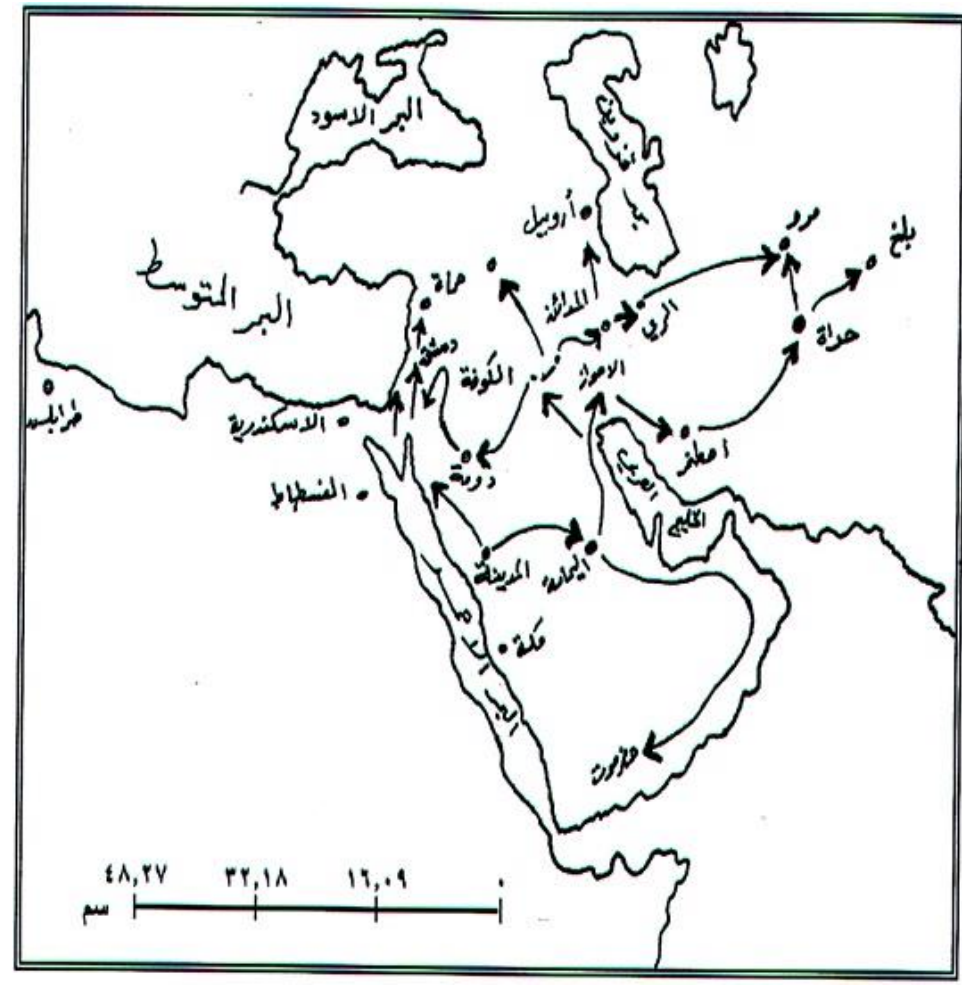

شكل رقم1: أنتشار الإسلام حتى عام 41 هـ [1].

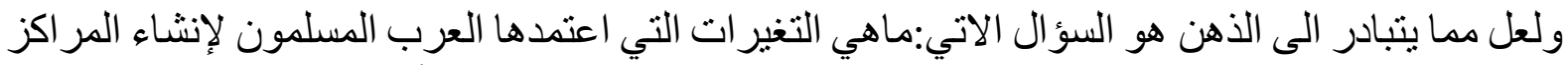

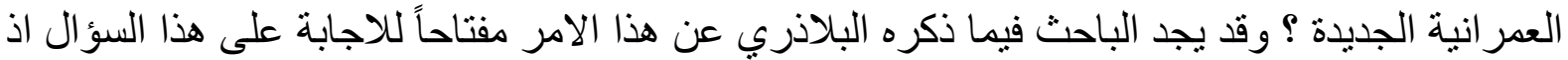

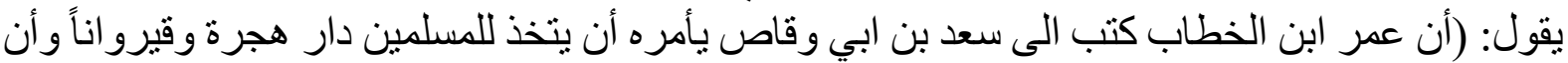

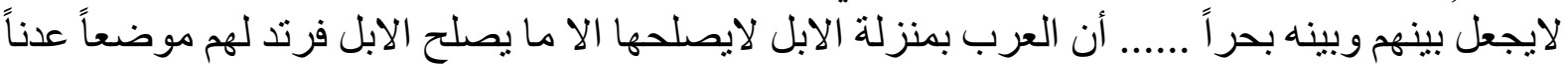

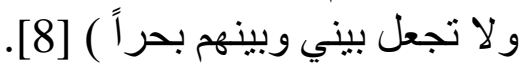

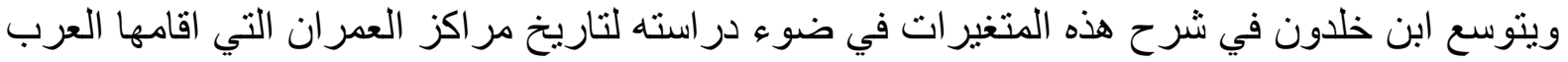

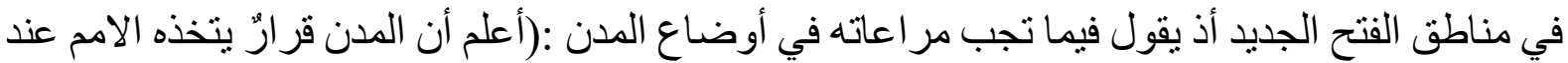

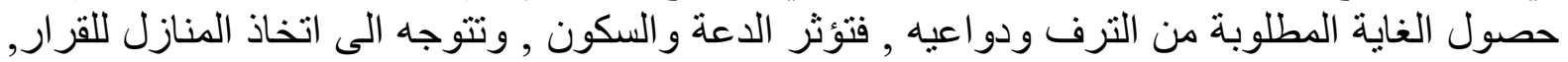

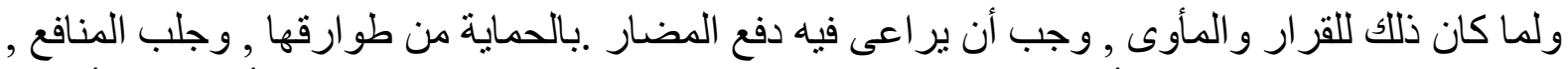
و تسهيل المر افق لها) ويذهب أبن خلدون الى التوسع في شرح هذه هذه المتغير ات فيقول : ( أن العرب أتخذوا

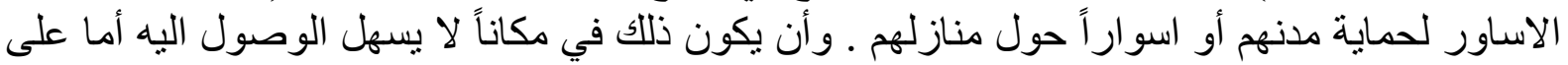

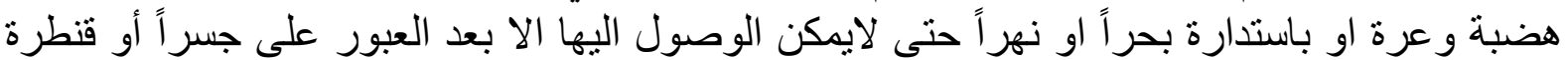


فيصعب منالها على العدو) [3]. وفي هذا المجال نر اه يؤكد على الجانب السوقي العسكري لاغر اض الدفاع

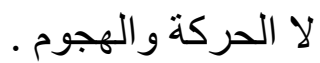

كما ذكر اختيار الاماكن التي تتمتع بطيب الهواء للسلامة من الامر اض ثم ينتقل ابن خلدون الى ما يتعلق

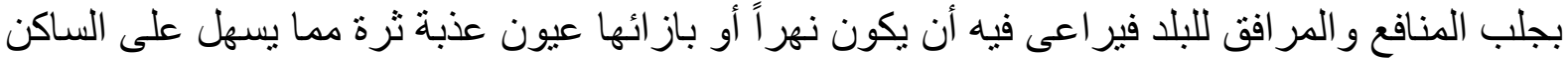

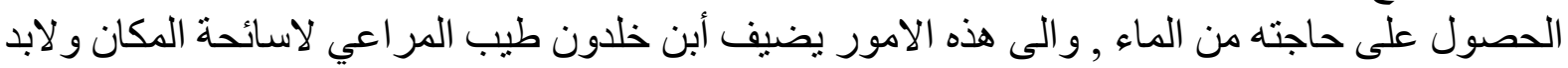

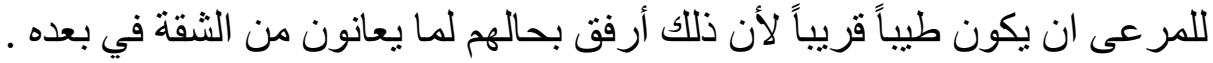

ولاحظ ابن خلدون أن العرب كانوا ير اعون قرب المزارع من البلد بما في ذلك الثجر والحطب والبناء

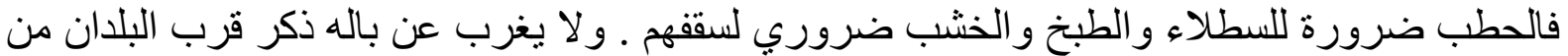

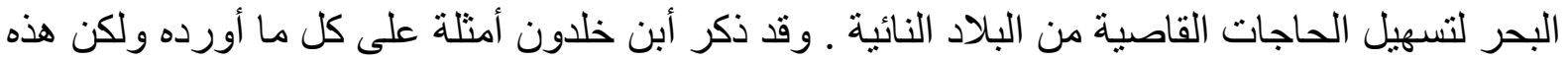

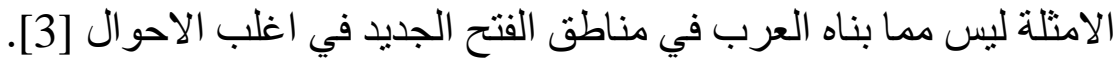

يتبين مما سلف ذكره أن الخليفة الر اشدي عمر بن الخطاب (رض) قد أخذ بنظر الاعتبار أمرين أساسين

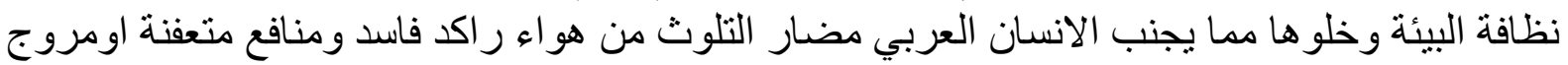

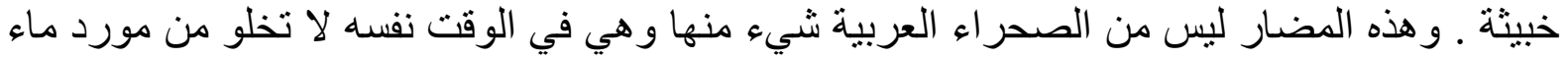

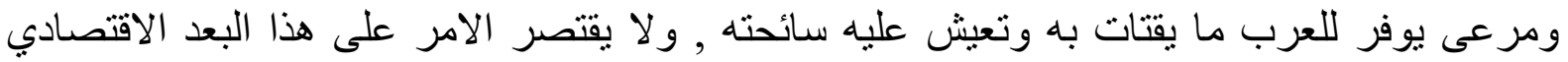
و الصحي و انما يذهب أمر الخليفة الى البعد السوقي العسكري .و لا عجب في في ذللك فالقيادة السياسية العليا

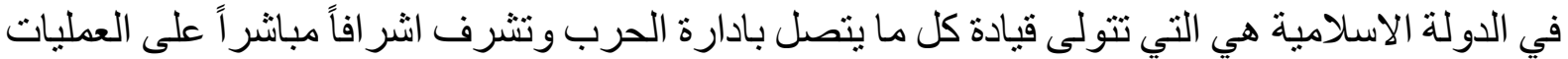

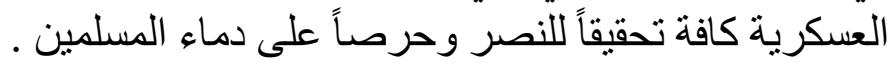

و هذه عناية بارزة واهتمام كبير بكل ما يقي المسلمين شر عدوهم ـ اذ يذكر الطبري أن اول كتاب كتبه

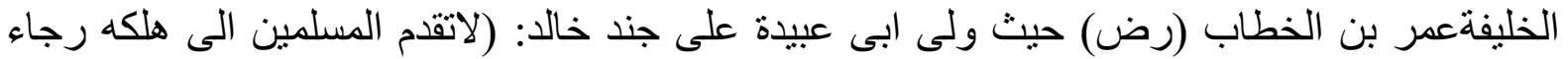

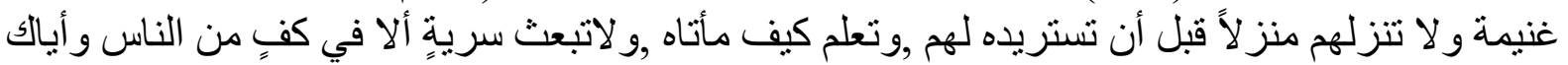
و القاء المسلمين في هلكه ) [9ن.

\section{الجوانب التطبيقية لاوضاع مراكز العمران}

تتمثل الجوانب التطبيقية للاطر النظرية في مر اكز العمران التي اقامها العرب في بدء عمليات الفتح ومنها

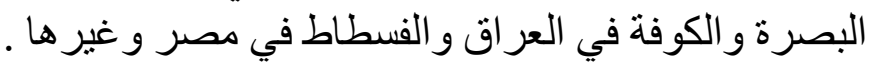

يقول البلاذري في تمصير البصرة :( أن عتبة بن غزوان لما نزل الخريبة كتب الى عمر بن الخطاب يعلمه

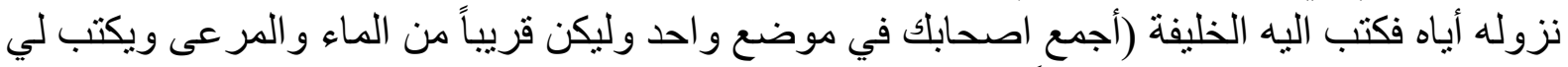

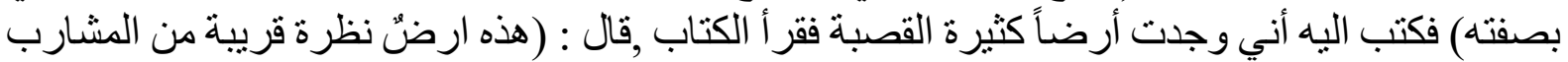

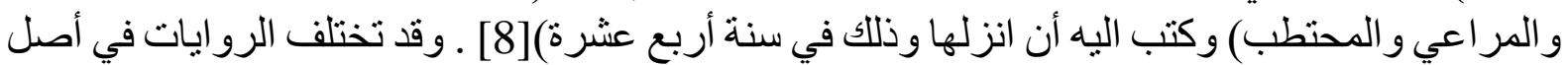

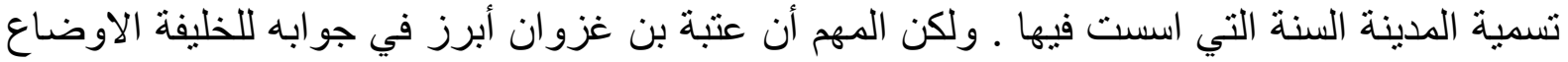

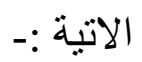

أـ قربها من مناقع الماء.

ب- وقو عها على طرف البر.

ج - كثرة القصب و القض (الحجار الصغير) 
و هذه شروط اساسية توفر للانسان العربي طيب العيش ولأبله وفرة المرعى وهذه من الامور التي أكد

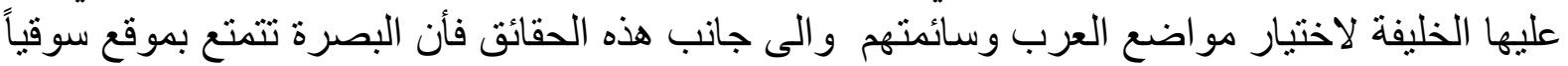

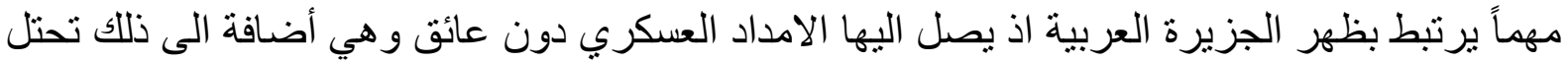

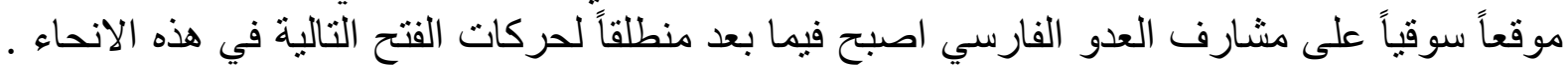

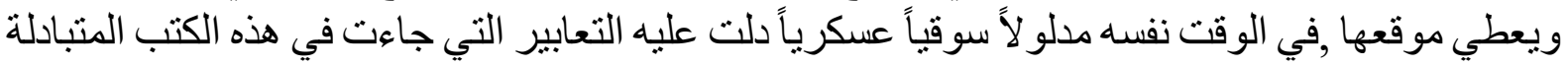
بين الخليفة وقائده مثل(على طرف البر) و (قريبٌ من الريف) او (طرف الصحر اءع) [10].

الكوفقة

تظهر المعالم الاقتصادية والسوقية العسكرية واضحة في اختيار موقع الكوفة اذ يقول البلاذري : (أن

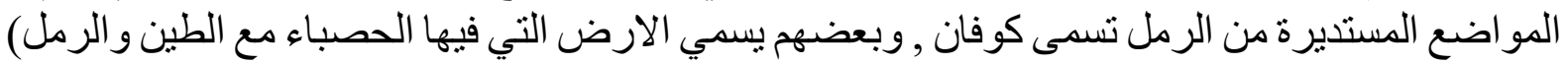

ويذهب الباحثون الى شروح مختلفة لتفسير أصل الكلمة والمهم أن سعد بن ابي وقاص لما افتتح القادسية

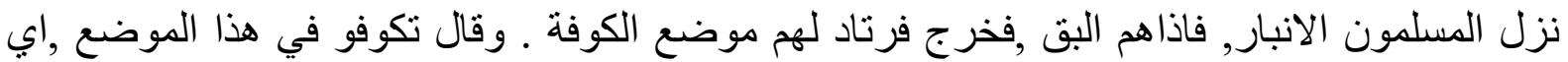

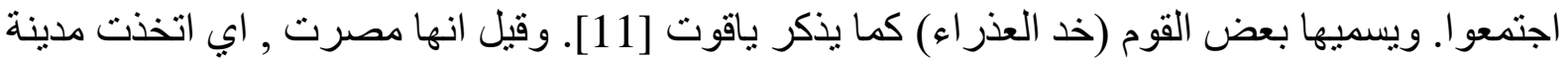
بعد البصرة بعامين في سنة (19 هـ) او قيل سنة (18 هـ) وقد وصف موقعها محمد بن عمير العطاردي:

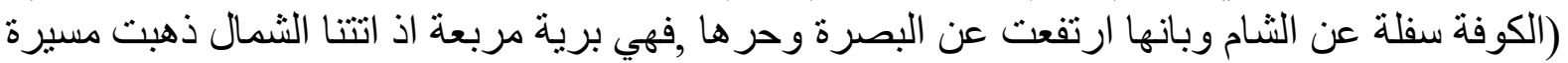

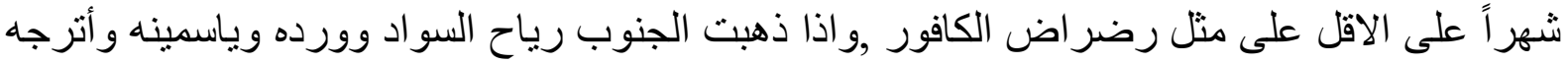

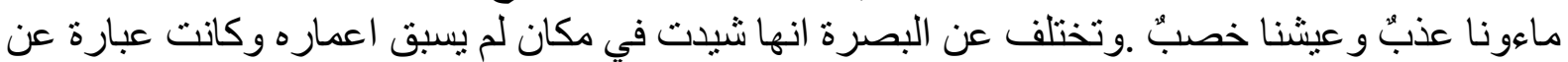
معسكر للجند ولذلك سميت (كوفة الجند) [12].

الفسطاط

تم بناء الفسطاط (مجتمع اهل الكورة حو الي مسجد وجماعتهم) وفقاً لضرورات الفتح الاسلامي ومتطلبات

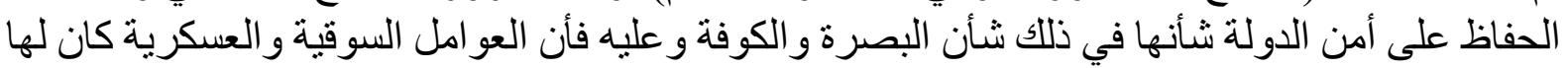

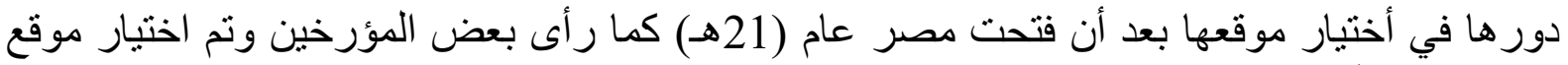

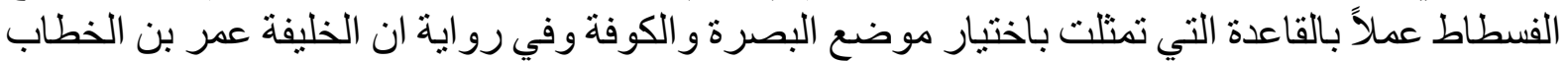

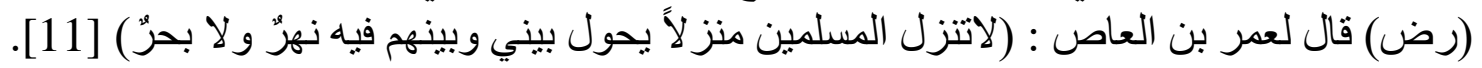
وفي أختيار موضع الفسطاط تبرز المعايير السوقية العربية في أختيار مواضع مر اكز عمر انهم حيث يكون الموضع على طرف البر متصلاً بالصحر اء يتيسر فيه الحصول على الماء ويقرب فيه المر عى و المحتطب.

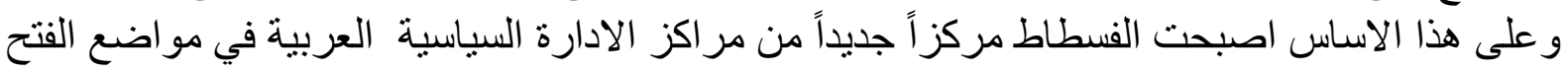
الجديد .و تختلف الروايات في تاريخ تمصير ها اذ امتدت من (20هـ) الى (22هـ).

لما استقرت أركان الدولة وقيض الله للعرب نشر دينه وكسر شوكة الكافرين التفت العرب الى الجانب

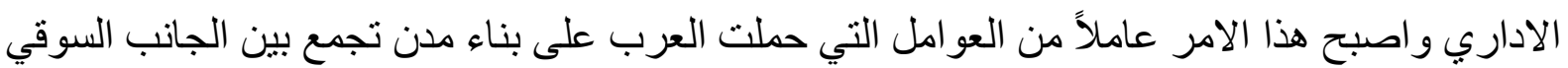

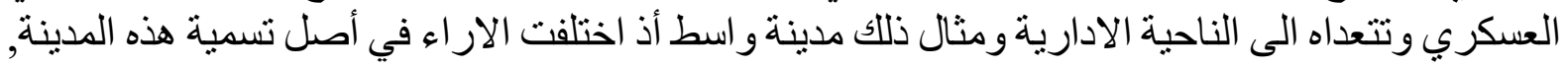

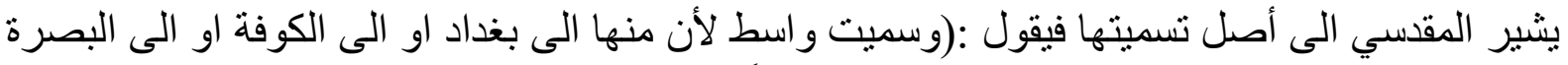

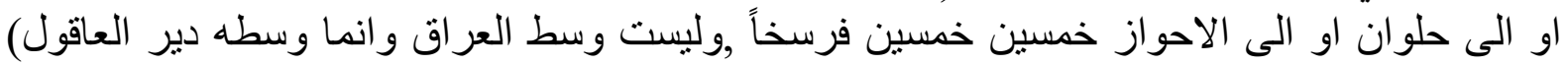

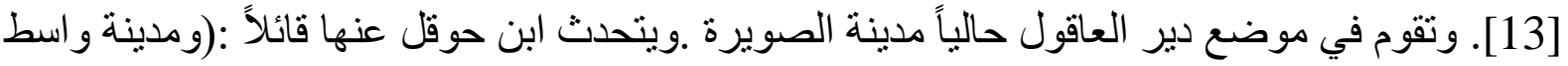

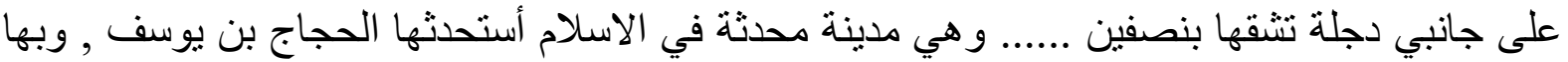

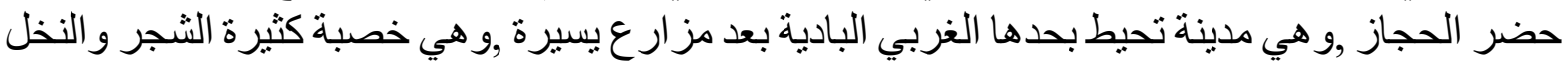
و الزرع) [14]. وقد بنيت في الربع الاخير من القرن الاول الهجري ويذكر ياقوت الحموي قدة إخئة اختيار 


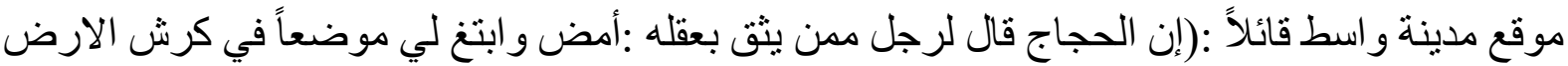

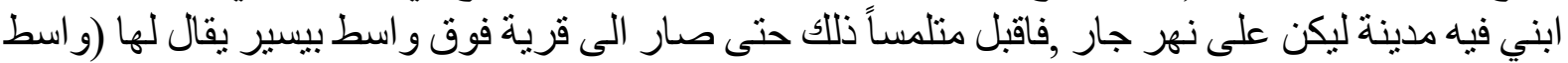

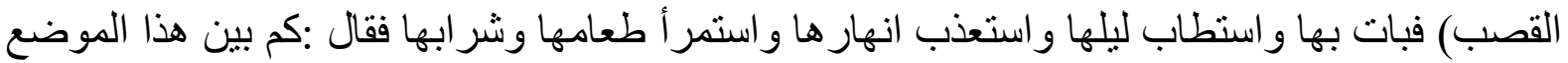

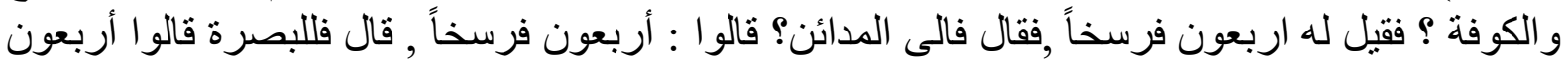

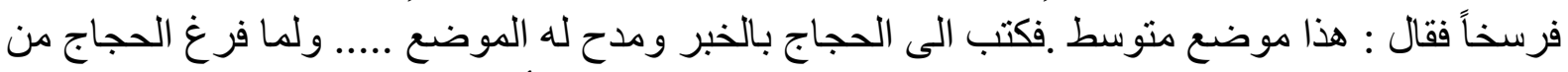

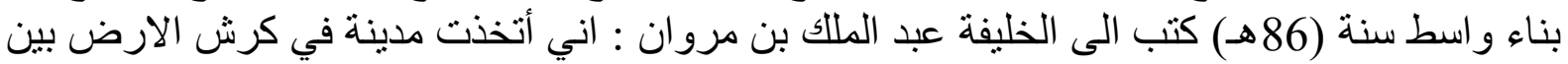

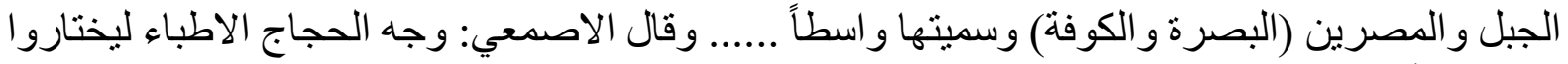

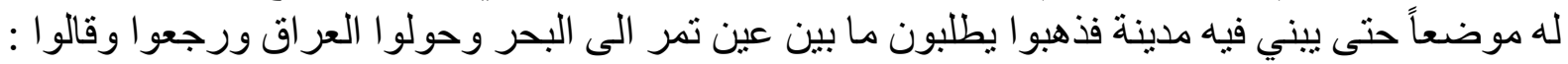

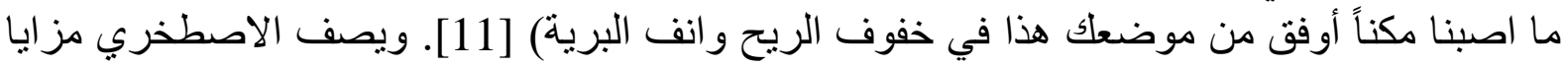
موضعها من الناحية المناخية فيقول :و هي أصح هو اء من الريح البصرة وليس لها بطائح [115].

بغداد

أختلف الباحثون في اصل أسم بغداد فقد قال البكري :بغداد فيها أربع لغات بدالين مهملتين , وبغداد معجمة

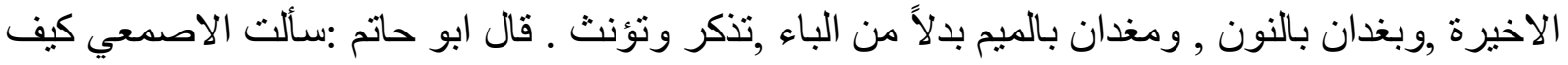

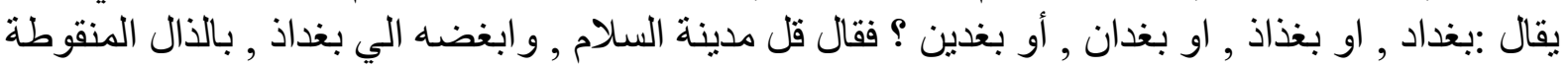

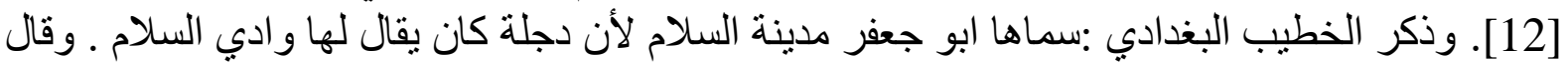

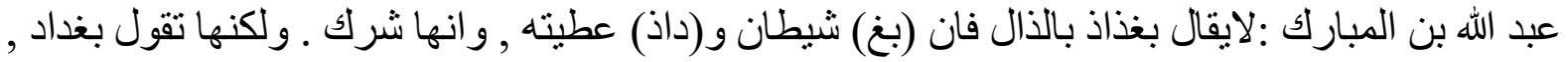

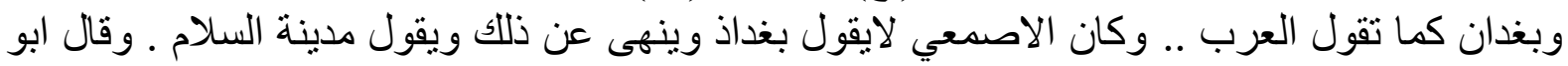

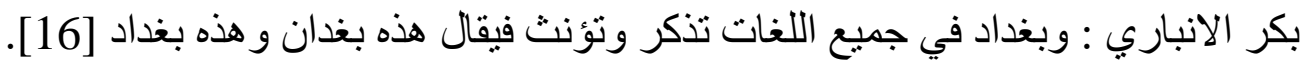

ويذهب بعض الباحثين المعاصرين بأن اصل التسمية يرجع الى البابلية (بعل جاد) بمعنى معسكر الالهة

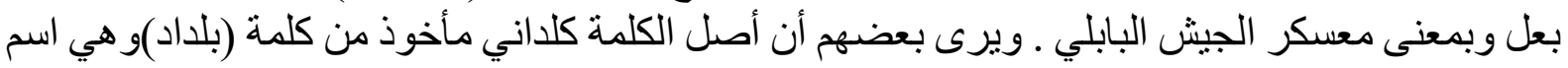

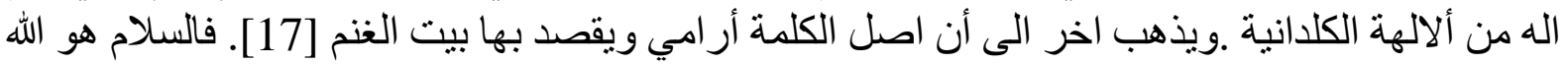

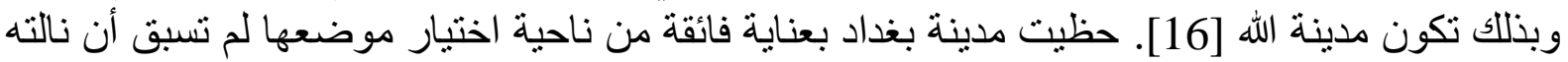

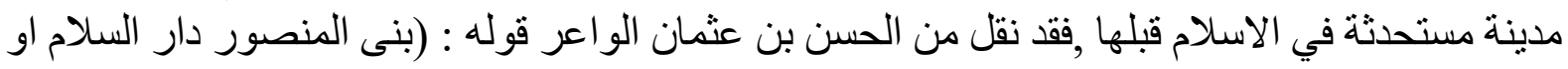

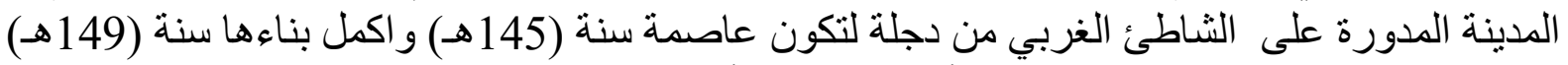

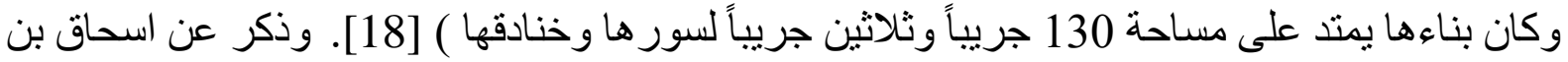

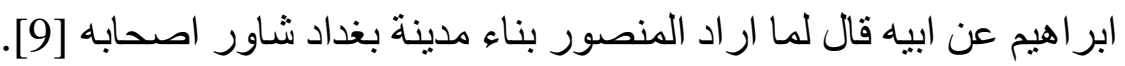

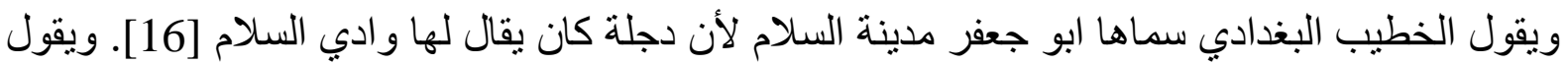

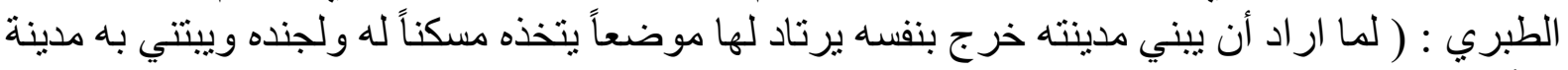

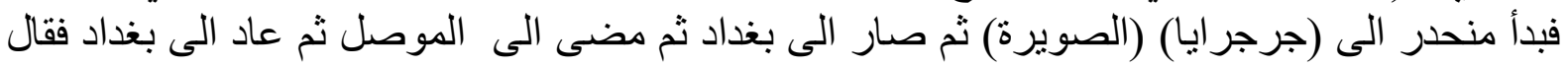

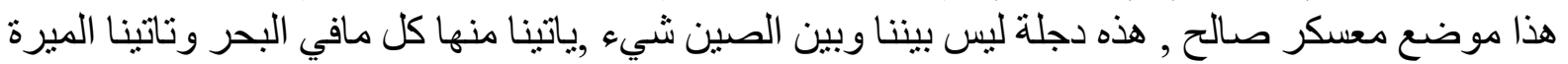

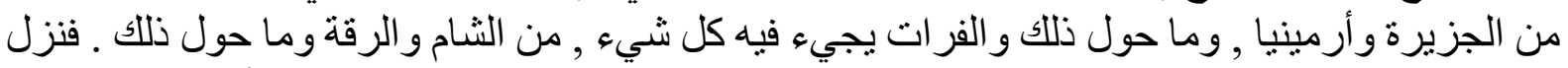

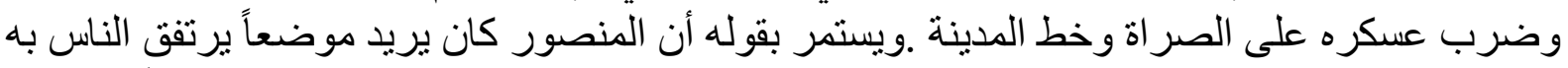

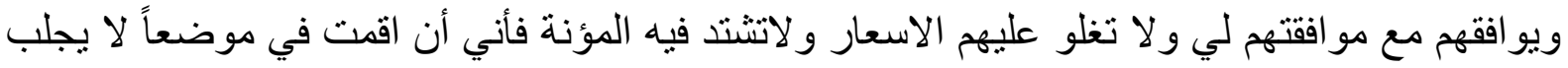

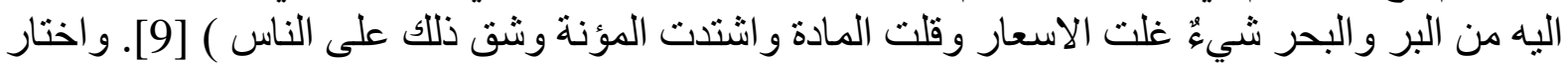

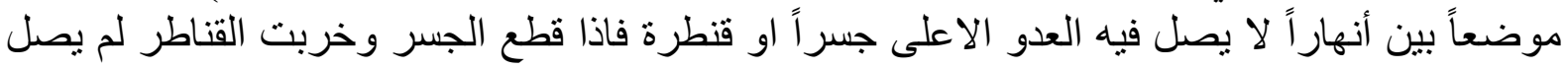
اليها العدو [9].

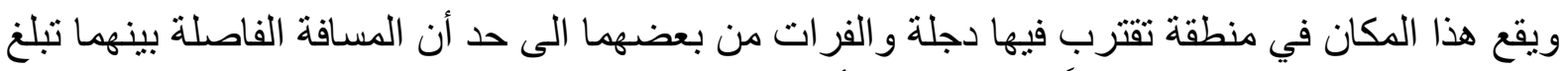

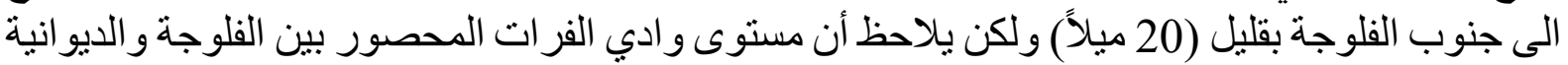


يعلو عن مستوى القسم المقابل من و ادي دجلة الممتد بين بغداد و الكوت فيبيما يبلغ الارتفاع في الفلوجة

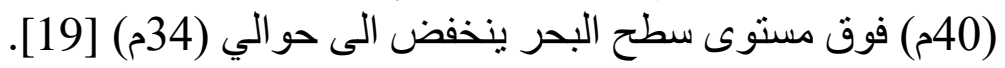

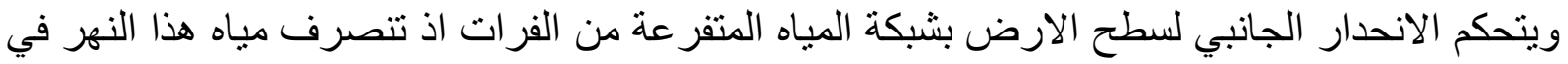

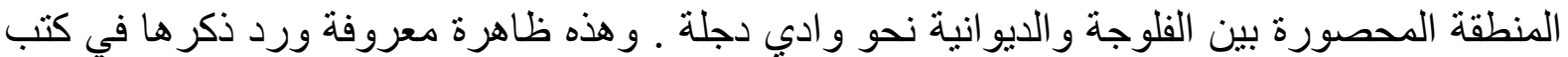
التز اث .

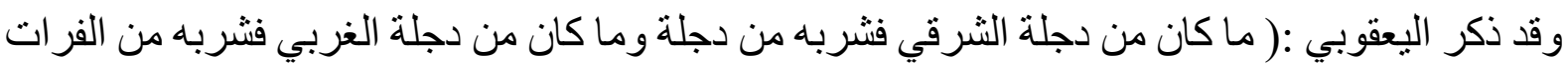

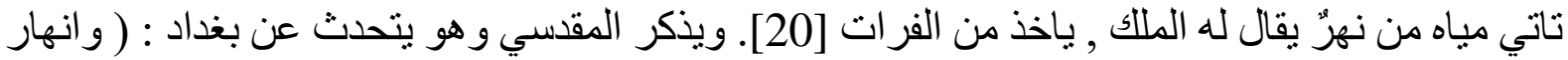

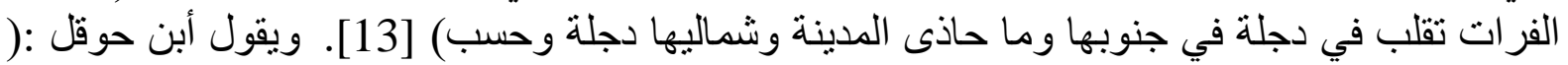

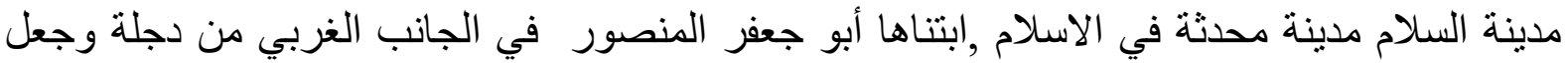

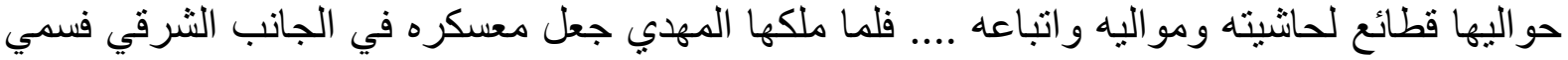

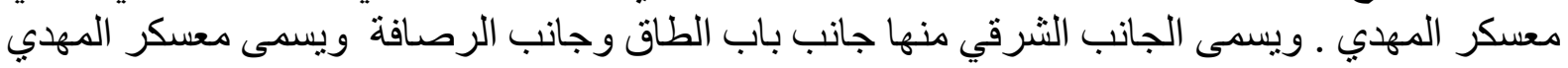

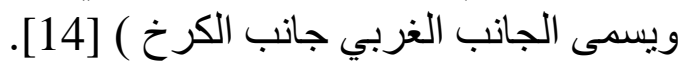

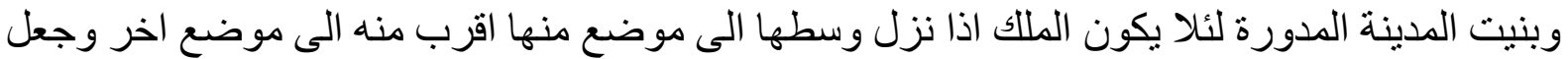

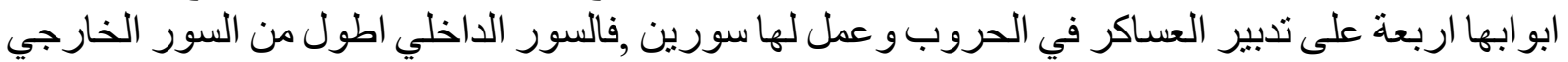
وبنى قصرّ في وسطها والمسجد الجامع حول القصر العربر [9].

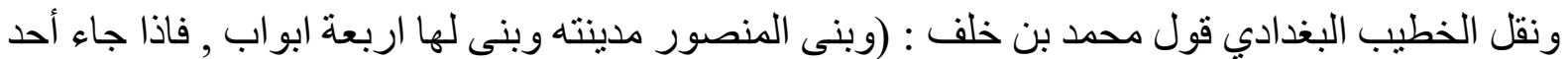

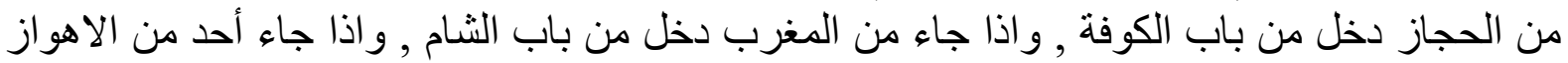

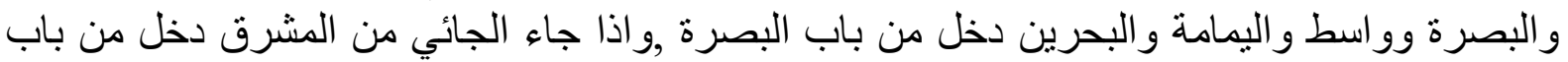

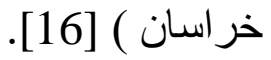

وذكر الخطيب قول وكيع :( أن ابا جعفر بنى المدينة مدورة لان المدورة لها معان سوى المربعة , وذللك

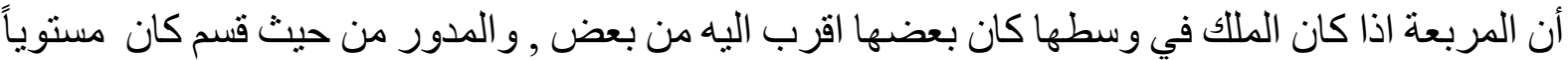

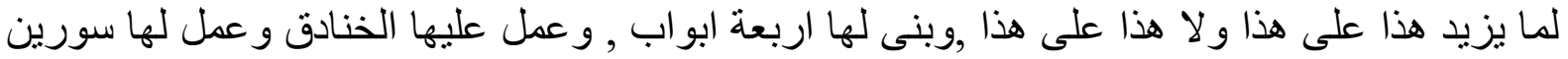

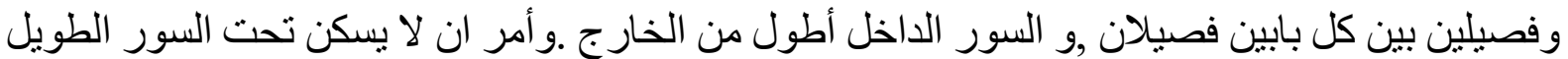

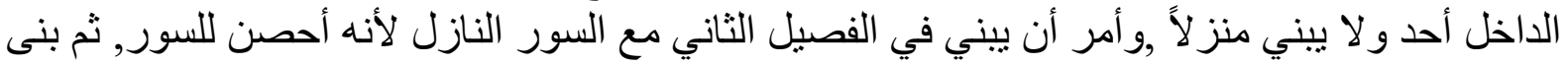

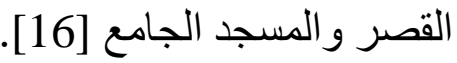

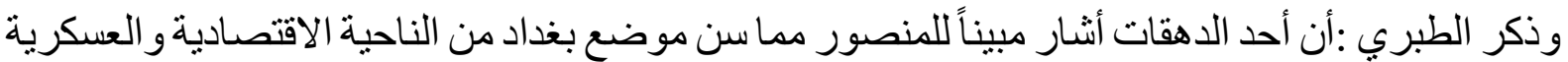

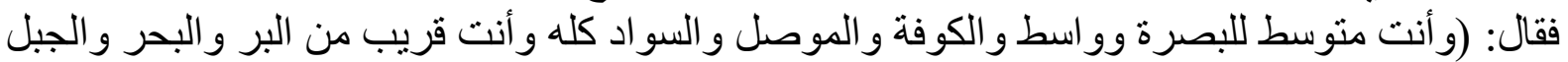

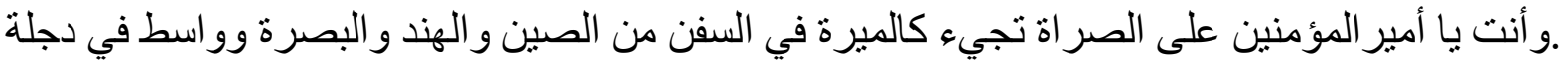

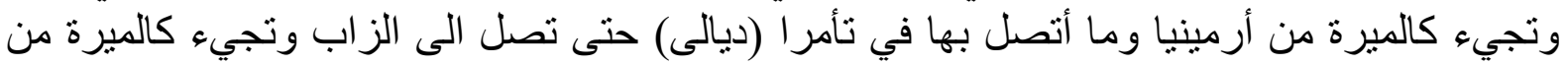

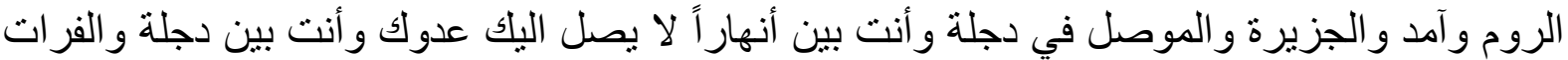

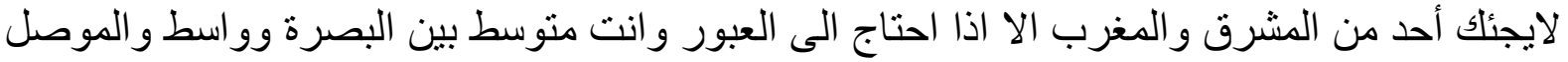

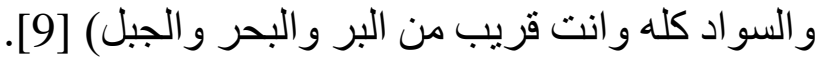

وكانت تنحدر من الفرات مجموعة من الانهار تسير بها السفن وتسقي الارض وض وهي نهر عيسى الذي يحتله

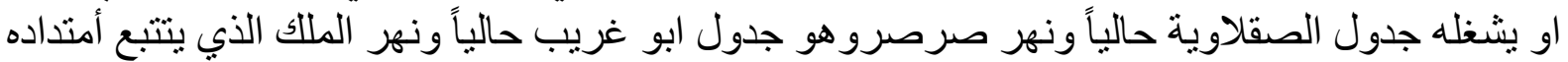

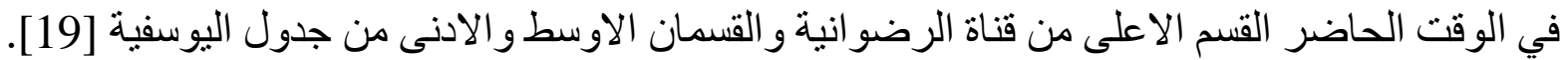

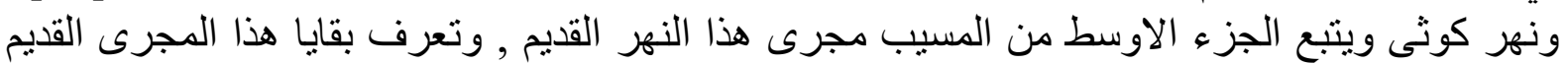

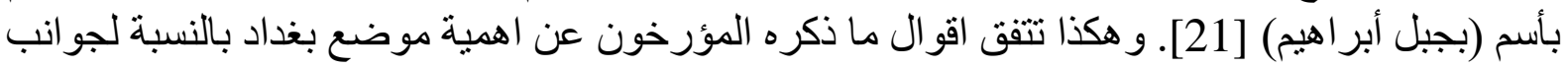
الحياة المختلفة وفطنوا الى اهمية شكلها الدائري ,فهذا الثكل من الناحية الهندسية يتميز بسعة مساحته 
وقصر محيطه و هذا يجعل أمر الدفاع عن المدينة ميسور اً باقل عدد من الجند وأن موقع الحاكم من وسطها

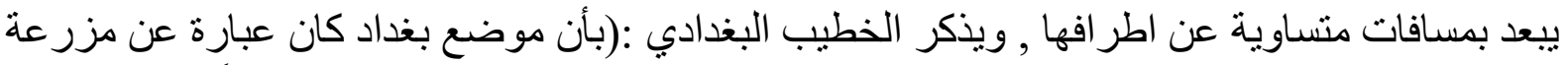

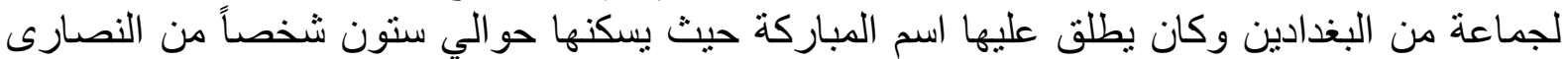

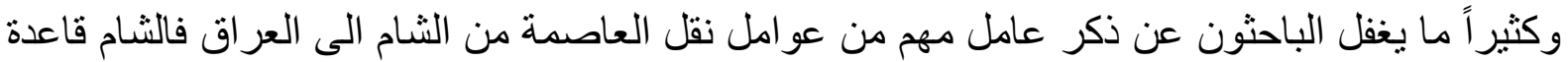

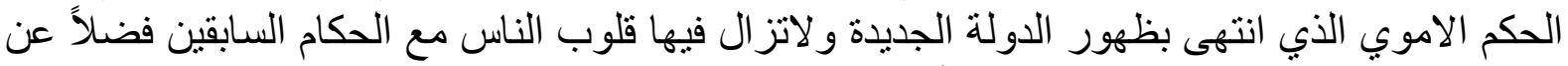

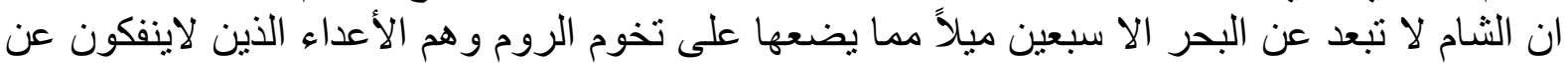

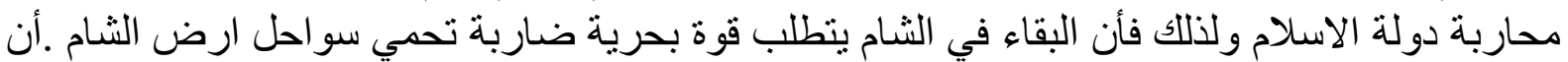

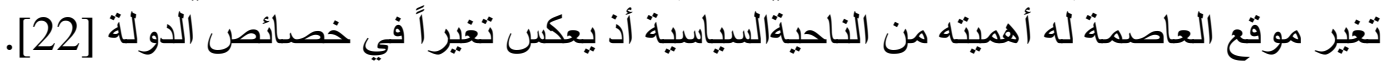

القبيروان

ذكر ياقوت الحموي قول الاز هري: (القيروان معرب) وقد تكلمت به العرب قديماً, القيروان مدينة عظيمة

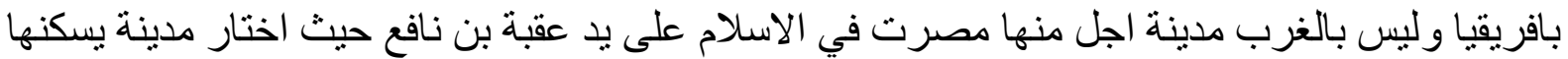

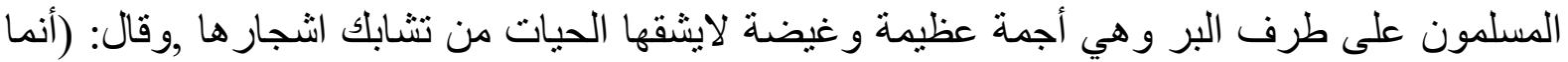

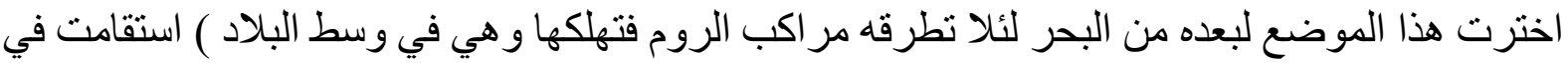

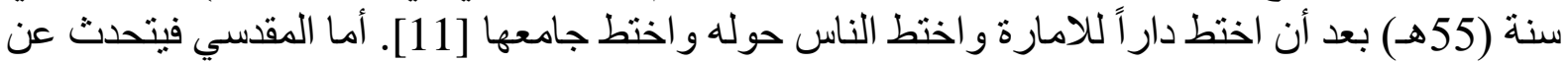

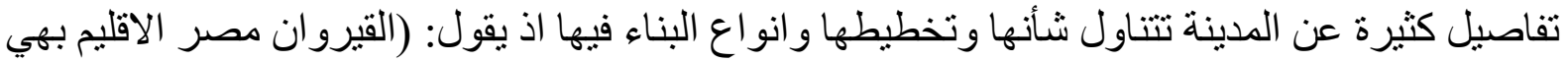

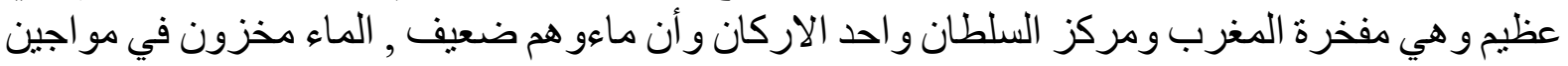

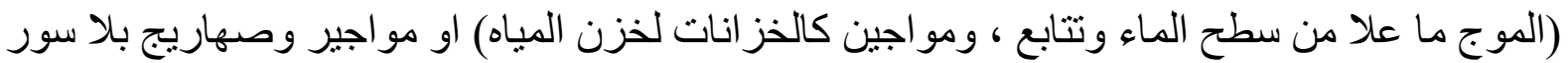

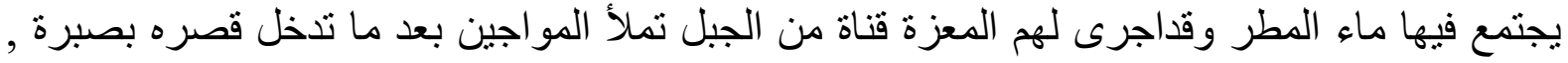

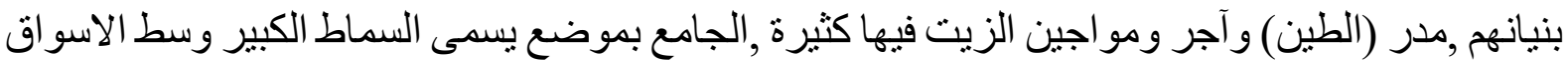

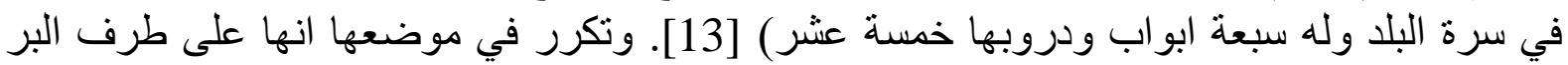

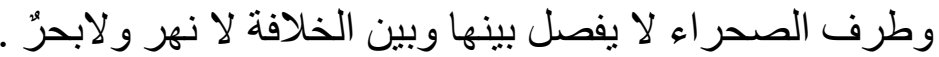

\section{سر من رأى}

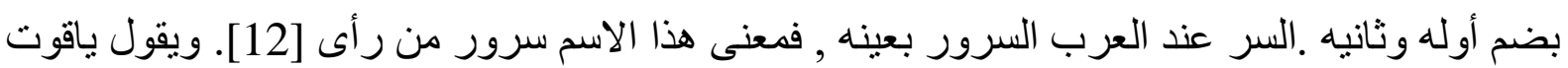

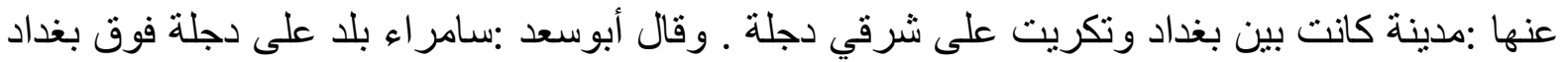

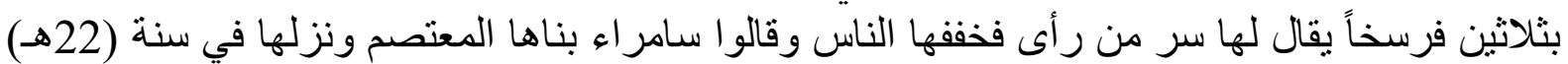

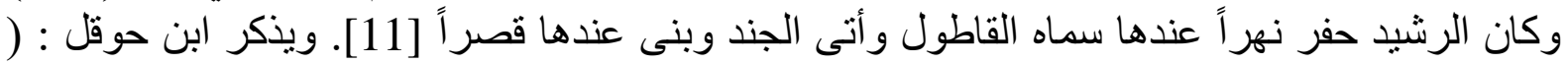

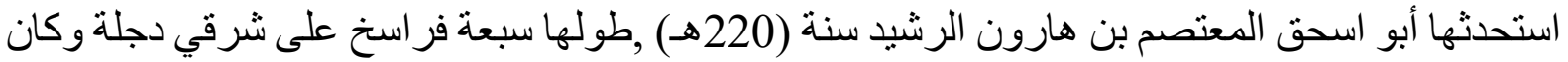

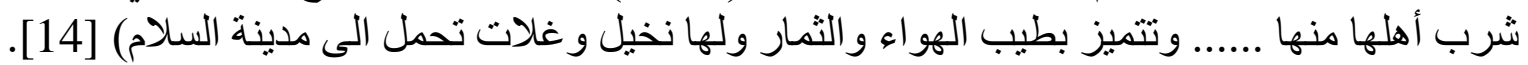
ويتحدث المقدي فيقول : (وكانت عجيبة حسنة حتى سميت (سرور من رأى) ـوتمتن بساتينها على الجانب

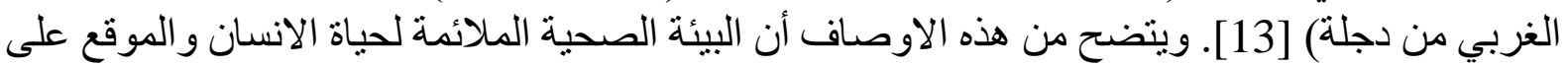

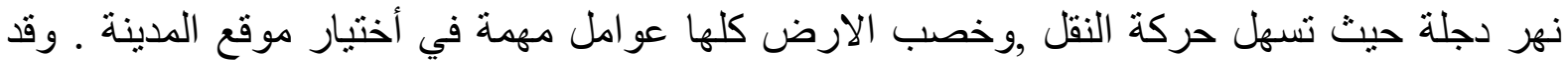

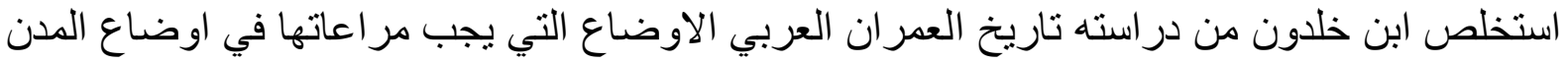
وماذا يحدث اذا اغفل ذلك عن المر اعاة و اكد على الجوانب العئ الاساسية الاتية : أــ العامل الاقتصادي تقضي الضرورة ان تكون المدن قريبة من الماء و المرعى و المحتطب . بـ العامل العكري الذي ير اعي ظروف المكان وامكاناته للاففاع عن النفس ودرئ اخطار المعتدين. تـ العامل الصحي الذي ير اعي طيب الهواء و الحماية من الافات . 
ومن هذا يتبين ان بعض ما عرضه ابن خلدون يساير القواعد الاساسية التي اعتمدها العرب في اختيار

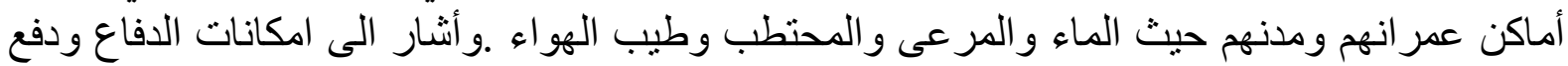

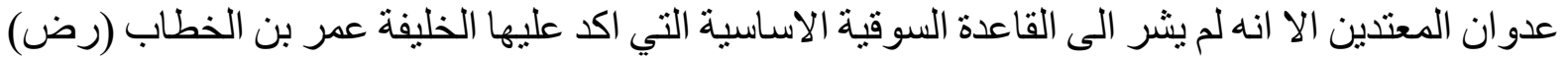

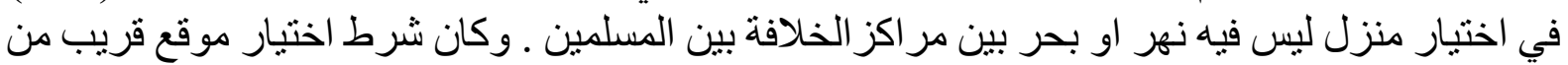

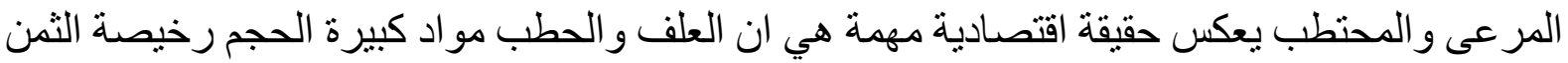

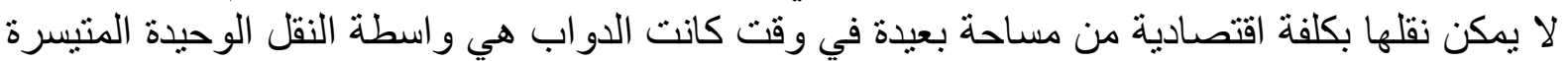

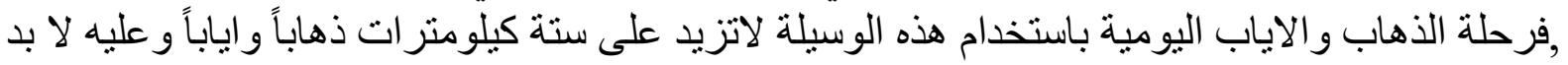

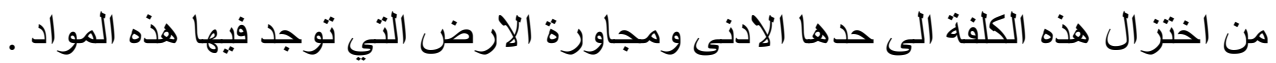

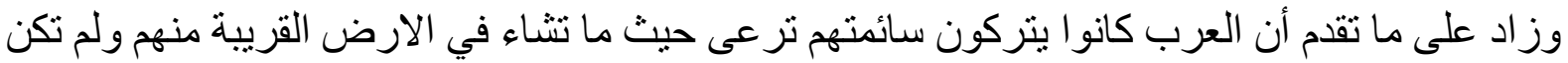

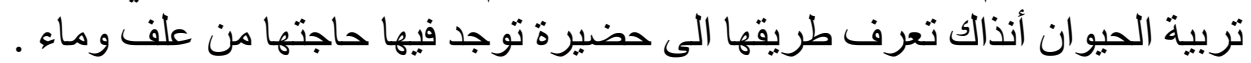

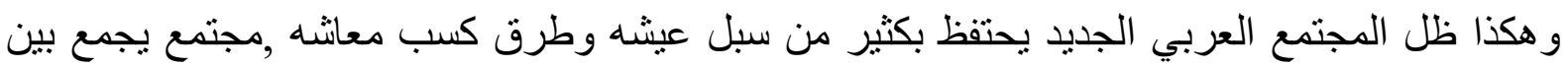

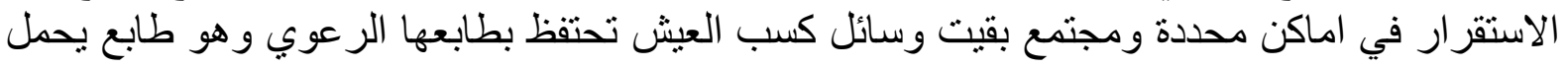

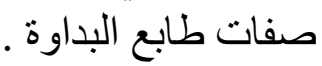

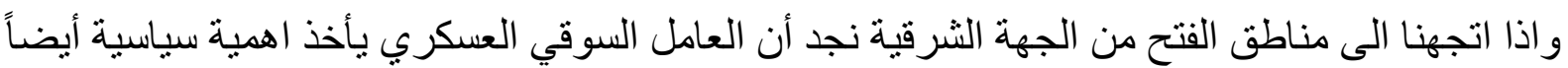

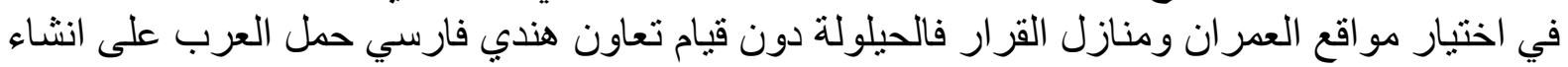

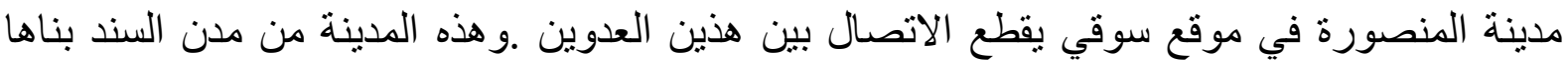

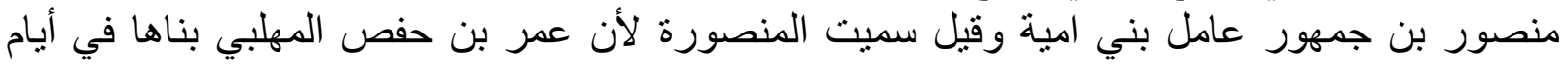
المنصور من خلفاء بني العباس فسميت باسمه [11] فئل

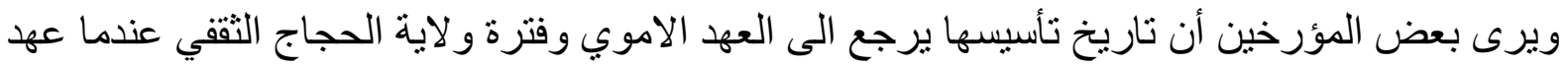

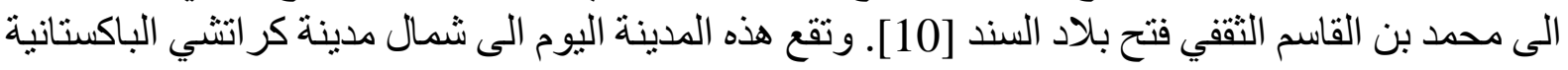

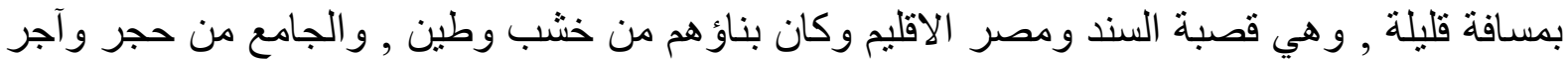

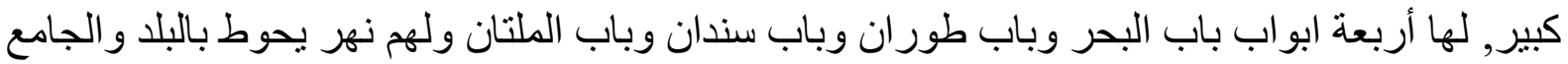

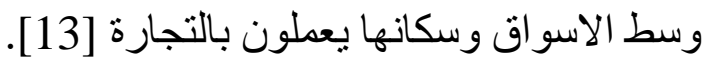

انها

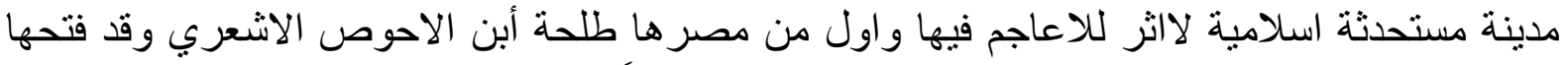

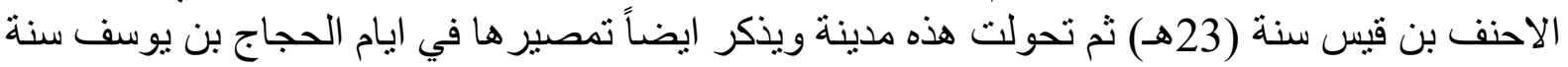

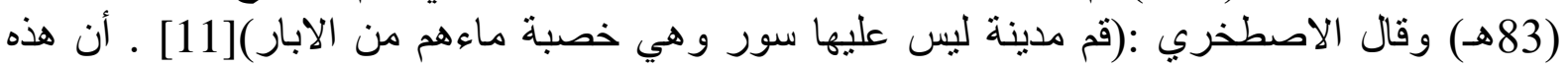

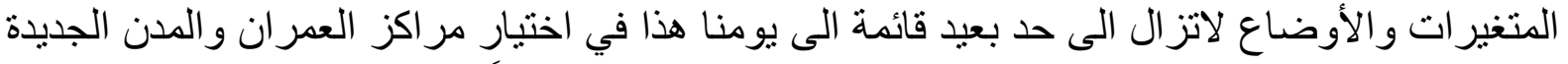

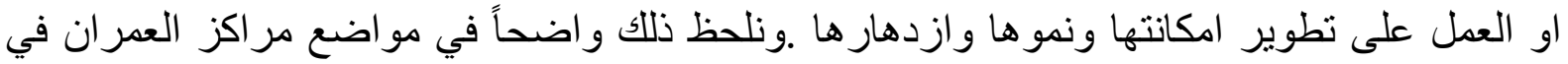

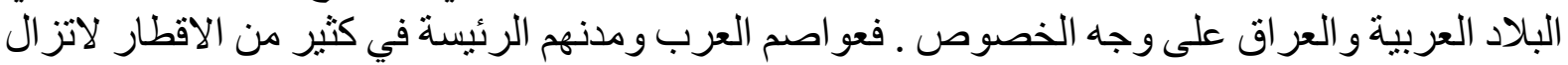

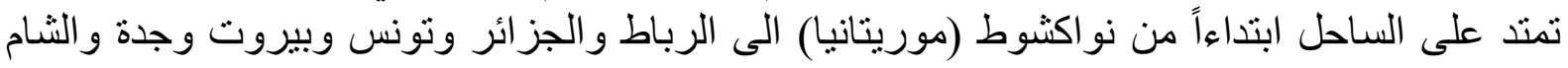

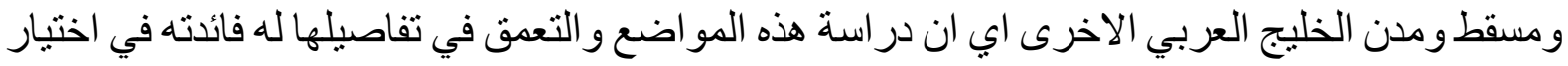

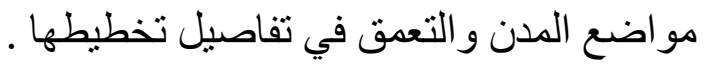

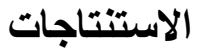

أــ تزخر كتب الادب الجغرافي العربي بذكر المدن والحواضر التي أختطها العرب واستقروا بها.

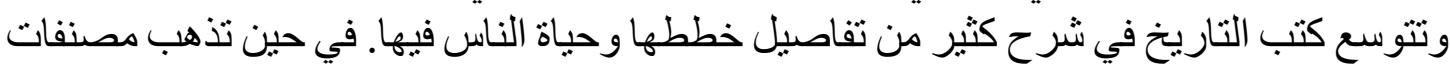

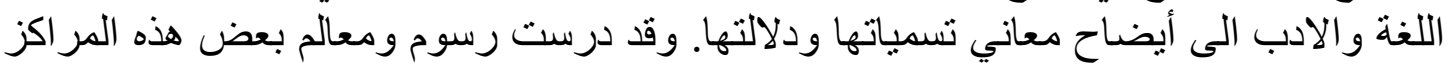

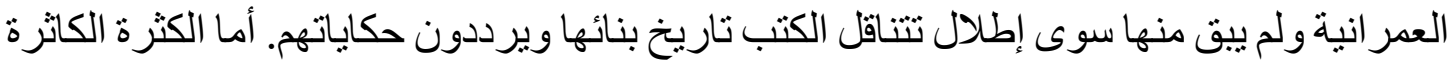




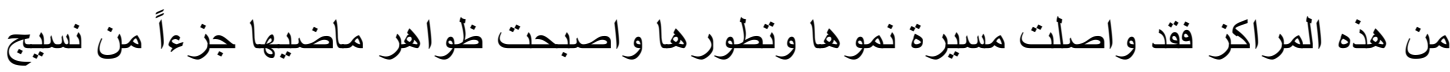

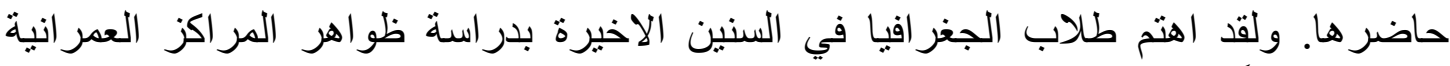
الحاضرة وفقاً لما جاء في الدر اسات الحديثة.

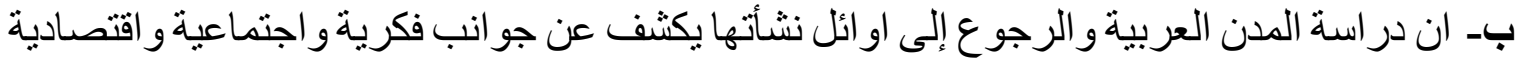

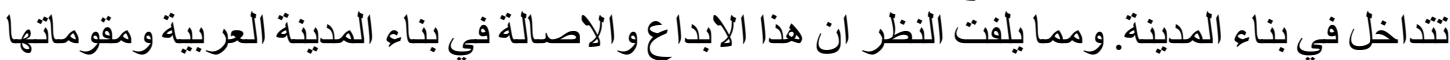

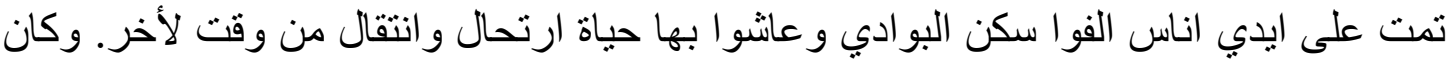

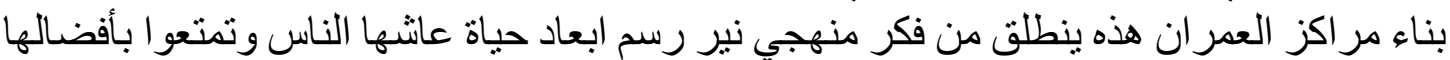

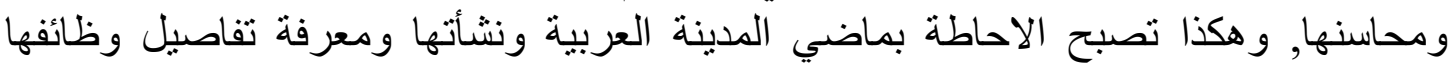
ضرورة علمية لابد منها في أي مشروع يتتاول در اسات الددن وتخطيطها

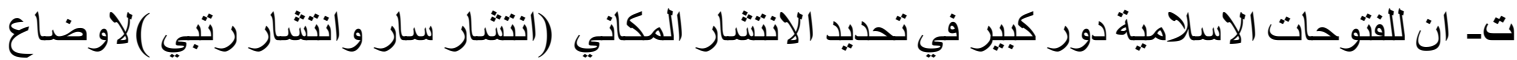

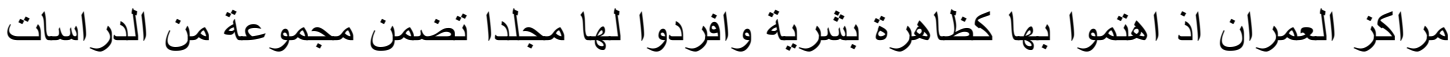

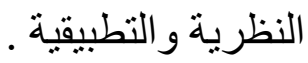

ثـ أخذ العرب بنظر الاعتبار في اختيار مو اقع مدنهم وحواضرهم اموراً اساسية اهمها: البعد السوقي

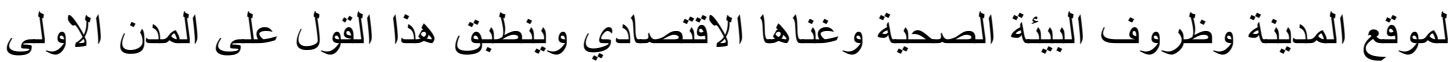

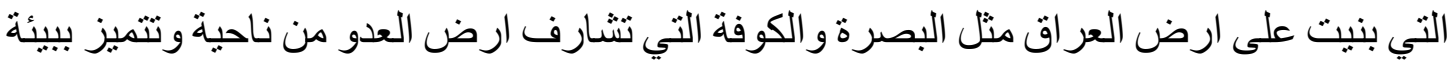

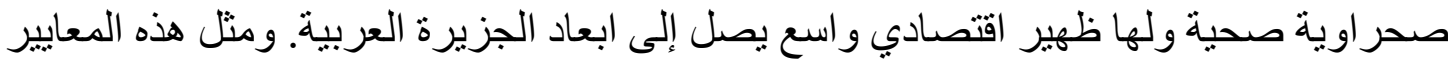
طبقت في اختبار موقع واسط و الفسطاط و القيروان ومن ثم بغداد.

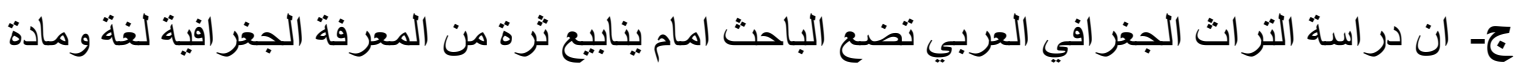

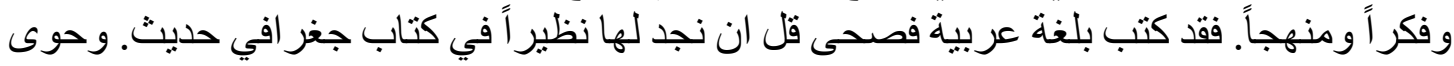

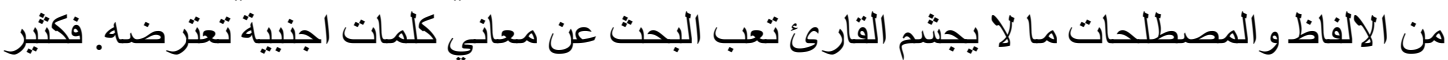

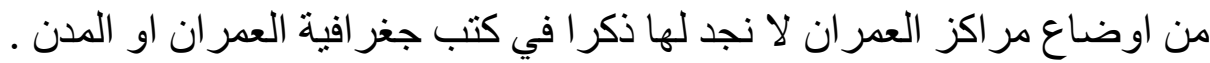

1. شاكر خصباك, كتابات مضيئة في التراث الجغر افي العربي, مطبعة دار السلام, بغداد, 1979.

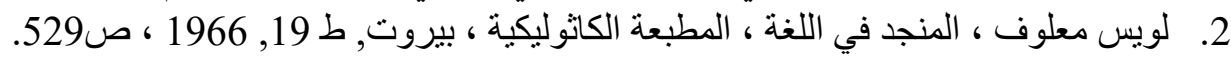

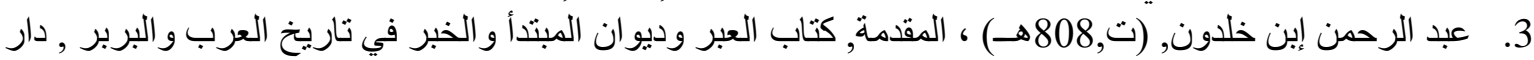

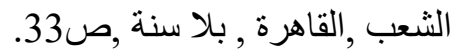

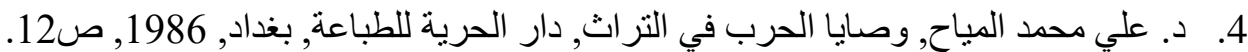

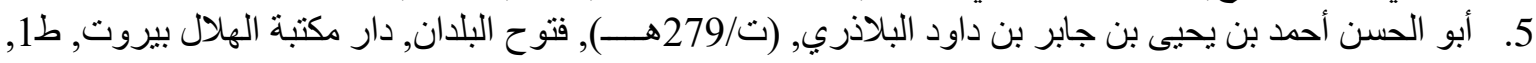

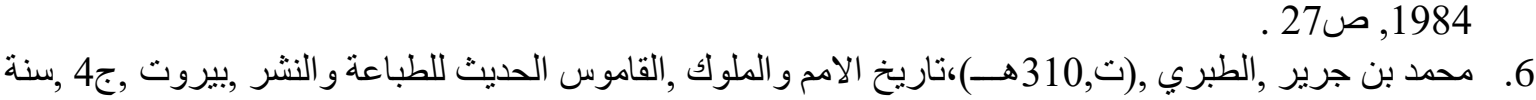

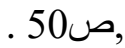

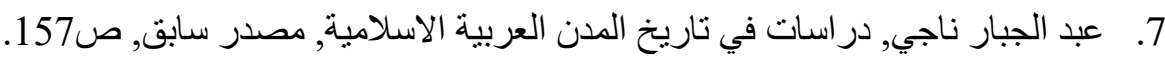

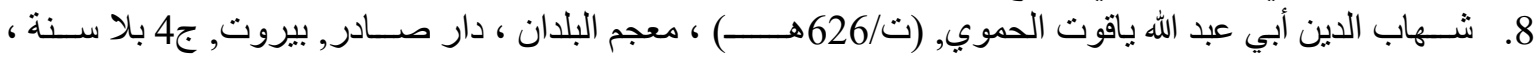

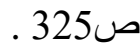

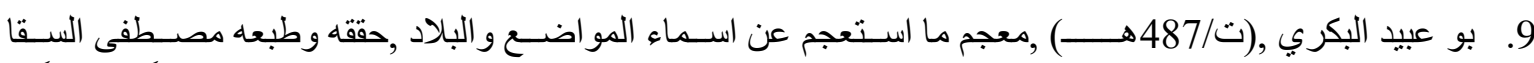

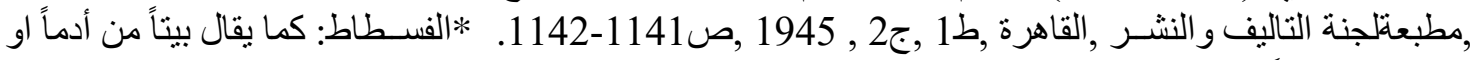

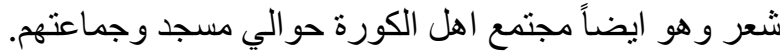

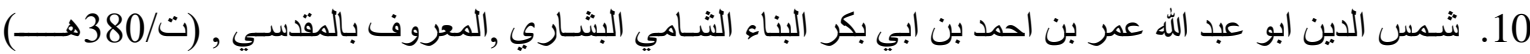

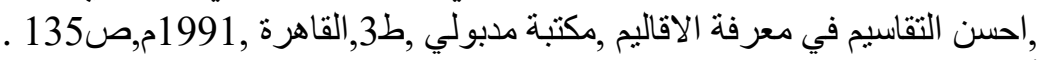

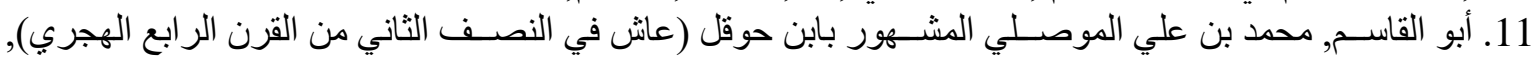

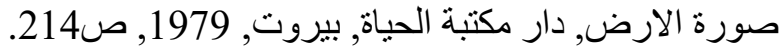


12. ابو اسحق, ابر اهيم بن محمد الاصطخري المعروف بالكرخي, (ت حو الي 350 هـــ) مسالك الممالك مطبعة بريل,

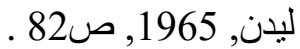

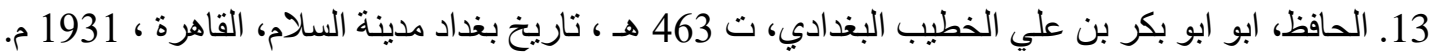

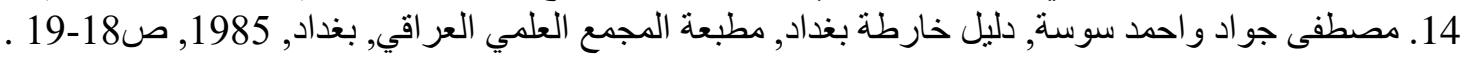

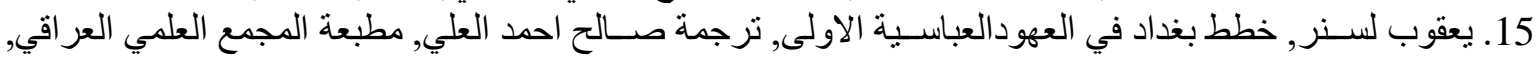

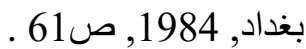

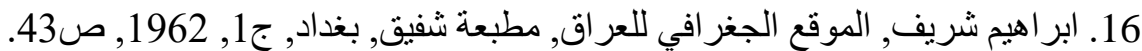

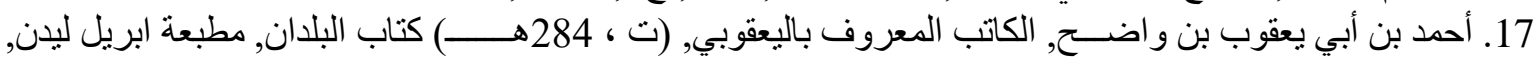

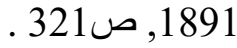

18. طه باقر, مقدمة في تاريخ الحضار ات, دار البيان, بغداد, 1974, ص48. صأن

19. Lawrence A. Brown, Guest Editor, Studies in spatial Diffusion Process Empirical Economic Geography, Clark University Worcester, Mass. Vol. 50 No. 4. 1974.

20. Jui -cheng Huang and Peter Gould, Diffusion in Urban Hierarchy. Economic.

Geography, Vol. 50, No.4, 1970 pp. -300-340.

21. William C. Brice, Atlas of Islam, op. Cit, pp6-8 William C. Brice, Editor, An Historical Atlas of Islam, Edinburgh, John Bartholome, P.6, 1981.

22. Van Valken burg and Carll, Stotz, Elements of political, Geography, prentice -Hall Inc., New York, 1954, p.62. 